Article

\title{
Profitability of Management Systems on German Fenlands
}

\author{
Marco Rebhann 1,2,*, Yusuf Nadi Karatay ${ }^{1,3}$, Günther Filler ${ }^{4}$ and Annette Prochnow ${ }^{1,2}$ \\ 1 Leibniz Institute for Agricultural Engineering and Bioeconomy, Max-Eyth-Allee 100, 14469 Potsdam, \\ Germany; ykaratay@atb-potsdam.de (Y.N.K.); aprochnow@atb-potsdam.de (A.P.) \\ 2 Chair Utilization Strategies for Bioresources, Faculty of Life Sciences, Humboldt-Universität zu Berlin, \\ Philippstraße 13, 10115 Berlin, Germany \\ 3 Division of Agricultural Policy, Faculty of Life Sciences, Humboldt-Universität zu Berlin, Philippstraße 13, \\ 10115 Berlin, Germany \\ 4 Farm Management Group, Faculty of Life Sciences, Humboldt-Universität zu Berlin, Philippstraße 13, \\ 10115 Berlin, Germany; guenther.filler@agrar.hu-berlin.de \\ * Correspondence: mrebhann@atb-potsdam.de; Tel.: +49-331-5699-215
}

Academic Editor: Iain Gordon

Received: 2 August 2016; Accepted: 22 October 2016; Published: 29 October 2016

\begin{abstract}
Fens are organic sites that require drainage for agricultural use. Lowering the groundwater level leads to trade-offs between economic benefits and environmental impacts (i.e., $\mathrm{CO}_{2}$ and nutrient emissions). To identify management options that are both environmentally and economically sustainable, a propaedeutic systematic analysis of the costs, income and profit of different land use and management systems on fenlands is necessary. This study provides an overview of the profitability, labor demand and comparative advantages of feasible management systems on German fenlands. Twenty management practices in four land use systems are analyzed. The results indicate that most management systems are profitable only with subsidies and payments for ecosystem services. In addition to sales revenue, these payments are indispensable to promote peat-saving agricultural practices on fenlands. Regarding the labor aspect, intensive management systems caused an increase in working hours per hectare, which may positively affect employment in rural areas. The calculations obtained in this study can be used as a basis for estimations of greenhouse gas (GHG) mitigation costs when management systems are associated with GHG emission values.
\end{abstract}

Keywords: organic soils; peatland; cost-efficiency; climate change; land use; farm management; milk; beef; biogas; combustion

\section{Introduction}

Approximately 3\% of the terrestrial surface is covered by organic soils, and 445,691 Gg of carbon are bound in peat [1] storing as much carbon as the earth's total biomass [2]. Additionally, organic soils provide ecosystem services such as storage, recycling and acquisition of nutrients, and accumulation of organic matter. They also influence microclimate by storing water, and provide habitats for a rich variety of fauna and flora [3].

Organic soils are divided into fens and bogs. Bogs are rainfed ombrotrophic organic soils, and fens are minerotrophic soils influenced by groundwater [4]. The groundwater level of fens is close to the soil surface [5] and determines land use options.

In Central Europe, fenlands have been made accessible for agricultural use by drainage over the past three centuries [6-8]. In the beginning, fens were used only with the slight lowering of the groundwater level to gain forage or litter for extensive livestock husbandry [6]. This process has been strongly intensified in the past 50 years with deep drainage for intensive cropland or grassland use [9], which has led to concerns with respect to environmental sustainability. The lowered groundwater 
level causes the loss of important ecological functions such as storage for water, carbon, nutrients, and habitats. Due to peat decomposition under aerobic conditions, the bound carbon is released to the atmosphere as $\mathrm{CO}_{2}$. Thus, drained peatland use is identified as an important source of greenhouse gas (GHG) emissions [1,9]. Over 25 million hectares of organic soils are drained worldwide [10]. According to management intensity, drained peatlands can be categorized as drained cropland, deep-drained nutrient-rich grassland, and shallow-drained nutrient-rich grassland, and rewetted fenlands [9]. Total greenhouse gas emissions $\left(\mathrm{CO}_{2}, \mathrm{CH}_{4}\right.$ and $\left.\mathrm{N}_{2} \mathrm{O}\right)$ decrease at lower management intensity from $34.38 \mathrm{t} \mathrm{CO}_{2}$ e. ha ${ }^{-1}$.year ${ }^{-1}$ for drained cropland to $26.38 \mathrm{t} \mathrm{CO}_{2}$ e. $\mathrm{ha}^{-1}$.year ${ }^{-1}$ for deep-drained nutrient-rich grassland, and $16.45 \mathrm{t} \mathrm{CO}_{2} \mathrm{e} . \mathrm{ha}^{-1} \cdot \mathrm{year}^{-1}$ for shallow-drained nutrient-rich grassland [9]. Rewetting of fenlands is discussed as a GHG mitigation option [11,12] reducing total greenhouse gas emissions to $9.90 \mathrm{t} \mathrm{CO}_{2} \mathrm{e}$. ha ${ }^{-1}$.year ${ }^{-1}$ [9]. However, rewetting severely restricts land use.

There is a lack of studies assessing the trade-offs between the environmental and production functions of fenlands. For such comparative analyses, it is necessary to estimate the cost structures and net returns of management practices on fenlands. This includes analyses of constrained mechanization and alternative production options on fenlands [13].

Several economic aspects of management systems on rewetted fenlands have been analyzed at farm and regional levels in previous studies. They examine the economic efficiency of single crops or single land use systems on fenlands [14-17], charcoal production from biomass of near-natural fenlands [18], and calculations of GHG mitigation costs of peat conservation $[19,20]$. A systematic analysis of the costs and revenues of different land use and management systems on fenlands has not yet been conducted. However, such an analysis is needed to compare the profitability of utilization options for fenlands, to provide data for subsequent calculations of GHG mitigation costs and to identify management options that are both environmentally and economically sustainable. Such information is necessary to estimate microeconomic and macroeconomic efficiency for fenland use.

The objective of this study is to provide an overview of the profitability, labor demand and comparative advantages of land use and management systems on fenlands. We define 20 management practices in four land use systems, and we calculate the costs, income, and net return for each system. According to the outcome of the analysis, we determine profitable, low profitable, and unprofitable management systems on the farm scale.

\section{Materials and Methods}

\subsection{Land Use and Management Systems}

We refer to natural conditions, common fenland management practices, and farm production data in the federal state of Brandenburg in northeast Germany. The annual mean temperature in Brandenburg is $9.4{ }^{\circ} \mathrm{C}$, and the annual precipitation is $567 \mathrm{~mm}$ (1986-2015) [21]. A total of approximately 159,000 ha fenlands are managed as cropland (11,000 ha), grassland (110,000 ha), forest (30,000 ha) and near-natural fen (8000 ha) [22].

Based on common practice in Brandenburg, we consider four main land use systems on fenlands: cropland, intensive grassland, extensive grassland, and near-natural fen. The land use systems differ in their groundwater level and management intensity. Within these land use systems, we define 20 management systems based on management intensity and main products (Table 1). 
Table 1. Characteristics of management systems considered in the study.

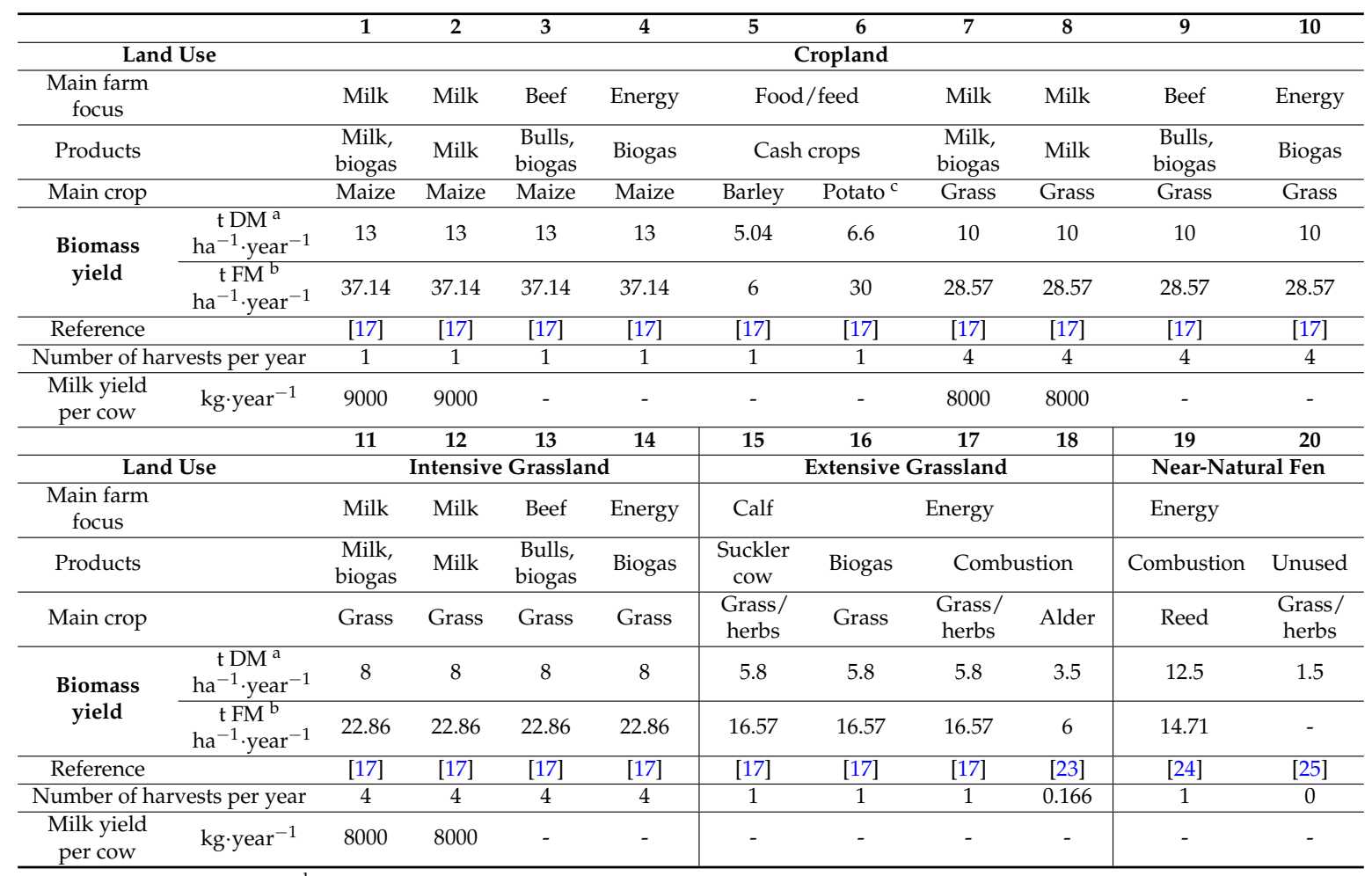

${ }^{a}$ DM: Dry matter; ${ }^{\mathrm{b}}$ FM: Fresh matter; ${ }^{\mathrm{c}}$ After sorting out, $27 \mathrm{t}$ FM sold as potato for food and $3 \mathrm{t}$ FM for feed.

Cropland is land used for the cultivation of crops [26]. Within this land use system, we consider ten management systems to produce cash crops, milk, beef and/or biogas (Table 1). Maize, barley, potato, and field grass are the crops analyzed in this study. Mineral and/or organic fertilizers are applied to the amount of nutrients removed. Depending on crop rotation, one or more harvests per year are conducted. Groundwater levels are lowered to at least $0.6 \mathrm{~m}$ below the surface to ensure oxygen supply in the crop root zone and to enable machinery operations [13,27]. This land use system is in line with the Intergovernmental Panel on Climate Change (IPCC) management practices of cropland and managed grassland on drained inland organic soils [9].

Intensive grassland is considered permanent grassland used for five years or more for forage grasses and herbs that are regularly re-seeded, fertilized, and subject to weed control [26]. Within this land use system, we distinguish four management systems: the production of milk or beef, the combined production of milk/beef and biogas, and sole biogas production (Table 1). Three to five harvests per year are common practice [28-30]. To achieve yields up to $12 \mathrm{t}$ dry mass (DM) per hectare and year, mineral and/or organic fertilizers are applied several times a year with a total amount of up to $380 \mathrm{~kg} \cdot \mathrm{N} \cdot \mathrm{ha}^{-1} \cdot \mathrm{year}^{-1}$ [31]. In periods of machinery operation, groundwater levels should be lowered to at least $0.5 \mathrm{~m}$ below the soil surface [32]. Similar to cropland, this management system is in line with the IPCC management practices of cropland and managed grassland on drained inland organic soils [9].

Extensive grassland is defined as permanent grassland with annual and perennial self-seeding vegetation. It is endemic and managed without re-seeding, fertilization, or weed control [26]. Fertilization occurs only by excreta remaining in the field in case of grazing. Biomass is harvested usually twice a year. In periods of machinery operation, the groundwater level is lowered moderately, to approximately $0.3 \mathrm{~m}$ below the soil surface. However, in individual cases, it can be considerably deeper [13]. Within this land use system, we differentiate four management systems: suckler cow husbandry, the production of hay or wood for combustion, and biogas production (Table 1). The land 
use system of extensive grassland is also in line with the IPCC management practices of managed grassland with a maximum groundwater level and low management intensity.

Near-natural fens are organic sites without the active lowering of the groundwater level. Therefore, groundwater levels are near the soil surface throughout the year. These sites are not fertilized. Vegetation is dominated by adapted native plant species such as common reed (Phragmites australis L.) and sedges (Carex spec. L.), which are not suitable for livestock feeding [33]. This type of land use is called paludiculture ("palus" means "mire" in Latin). We consider two management systems within this land use system: reed harvest for combustion and fenland without use (Table 1). This land use system corresponds to the rewetted organic soils according to the IPCC management practices of paludiculture [9].

\subsection{Profitability Calculation Approach for Fenland Management Systems}

\subsubsection{Income, Costs and Net Return (Profit)}

We calculate the income, costs, and net return for the 20 management systems for a model farm with 150 ha. We perform economic assessments for all management systems based on the same production steps and assumptions in order to assure comparability.

Income contains common items such as sales and earnings from subsidies. In the short run, income must be sufficient to pay variable costs. In the long run, income should be sufficient to pay all costs of production for resources to be used in their most profitable alternative. Net return (profit) can be estimated by combining income and costs.

The profit for $j^{\prime}$ s fenland management system $\left(\pi_{j}\right)$ is the difference between income $\left(I_{j}\right)$ and total production costs (TCj) (Equation (1)).

$$
\pi_{\mathrm{j}}=\mathrm{I}_{\mathrm{j}}-\mathrm{TC}_{\mathrm{j}}
$$

In every management system $j$, different numbers of products $n$ are generated. Income $I_{j}$ for $j$ 's fenland management system is calculated as the sum product of the yields for the products $\left(Y_{i j}\right)$ and their respective sales prices, $\mathrm{P}_{\mathrm{ij}}$. For example, in management system 1 , the products are milk $\left(Y_{11}\right)$ as well as energy $\left(P_{21}\right)$ and heat $\left(P_{31}\right)$ from biogas with their respective prices, $P_{11}, P_{21}$ and $P_{31}$. In system 5 , barley is the single product sold.

In our study, income is generated from sales of crops (barley, potatoes), milk, beef (bulls and slaughter cows), calves, and energy (electricity, heat). Earnings from subsidies $\left(S_{j}\right)$ and payments for ecosystem services $\left(\mathrm{PES}_{\mathrm{j}}\right.$ ) are added (Equation (2)). The data used for the economic calculations of land use and management systems are shown in Table 2.

$$
I_{j}=\sum_{i=1}^{n} P_{i j} Y_{i j}+S_{j}+P E S_{j}
$$

For our 150 ha-sized farm, we assume $259.58 € \cdot \mathrm{ha}^{-1} \cdot \mathrm{year}^{-1}$ of direct payment from the European Union (EU), which includes a $159.07 € \cdot$ ha $^{-1} \cdot$ year $^{-1}$ EU Basic Payment, an $87.11 € \cdot$ ha $^{-1} \cdot$ year $^{-1}$ "Greening" payment, and a $13.40 € \cdot \mathrm{ha}^{-1} \cdot \mathrm{year}^{-1}$ shifting payment. The restriction of a $5 \%$ set-aside area or ecological compensation area with different land use ratios under the "Greening" policy are not considered in our analysis. Furthermore, if groundwater level in extensive land use and near natural fens is kept between $0.1 \mathrm{~m}$ and $0.3 \mathrm{~m}$ below the surface over the entire year, $387 € \cdot \mathrm{ha}^{-1}$. $\mathrm{year}^{-1}$ as a payment for ecosystem services is additionally granted from an environmental scheme for peat-saving management in Brandenburg. Altogether, the EU subsidies and payments for ecosystem services can reach up to $647 € \cdot$ ha $^{-1} \cdot$ year $^{-1}$. 
Table 2. Data used for economic calculations of land use and management systems.

\begin{tabular}{|c|c|c|c|}
\hline Parameter & Unit & Value & Reference \\
\hline \multicolumn{4}{|l|}{ Overhead costs } \\
\hline Rent for cropland & $€ \cdot h a^{-1}$ & 131.00 & [34] \\
\hline Rent for intensive grassland & $€ \cdot \mathrm{ha}^{-1}$ & 90.00 & [34] \\
\hline Rent for extensive grassland & $€ \cdot \mathrm{ha}^{-1}$ & 45.00 & [34] \\
\hline Tax & $€ \cdot$ ha $^{-1} \cdot$ year $^{-1}$ & 7.67 & [15] \\
\hline Payment for ditch maintenance & $€ \cdot$ ha $^{-1} \cdot$ year $^{-1}$ & 9.05 & [35] \\
\hline Payment for ditch maintenance on natural fen & $€ \cdot$ ha $^{-1} \cdot$ year $^{-1}$ & 4.87 & {$[35]$} \\
\hline Labor costs & $€ \cdot \mathrm{h}^{-1}$ & 15.00 & [36] \\
\hline \multicolumn{4}{|l|}{ Government payments } \\
\hline EU basic payment (Brandenburg) & $€ \cdot \mathrm{ha}^{-1}$ & 159.58 & [37] \\
\hline Greening payment & $€ \cdot \mathrm{ha}^{-1}$ & 87.11 & [37] \\
\hline Shifting payment (first 30 ha) & $€ \cdot \mathrm{ha}^{-1}$ & 13.40 & [37] \\
\hline Extensive peat-saving management ${ }^{a}$ & $€ \cdot \mathrm{ha}^{-1}$ & 387.00 & [38] \\
\hline \multicolumn{4}{|l|}{ Producer prices } \\
\hline Barley & $€ \cdot \mathrm{t}^{-1} \cdot \mathrm{FM}$ & 158.40 & [39] \\
\hline Potato (food) & $€ \cdot \mathrm{t}^{-1} \cdot \mathrm{FM}$ & 142.00 & [39] \\
\hline Potato (feed) & $€ \cdot \mathrm{t}^{-1} \cdot \mathrm{FM}$ & 15.00 & [39] \\
\hline \multicolumn{4}{|l|}{ Seed/plant costs } \\
\hline Maize seed & $€ \cdot h^{-1}$ & 136.00 & [39] \\
\hline Barley seed & $€ \cdot h a^{-1}$ & 60.00 & [39] \\
\hline Potato seed & $€ \cdot \mathrm{ha}^{-1}$ & 856.00 & [39] \\
\hline Grass seed & $€ \cdot \mathrm{ha}^{-1}$ & 56.00 & [39] \\
\hline Young alder plants (4000 plants per hectare) & $€ \cdot \mathrm{ha}^{-1}$ & 2680.00 & [40] \\
\hline \multicolumn{4}{|l|}{ Other supplies } \\
\hline Diesel costs & $€ \cdot L^{-1}$ & 0.80 & [36] \\
\hline Nitrogen fertilizer & $€ \cdot t^{-1}$ & 960.00 & [39] \\
\hline Net for round bale & $€ \cdot \mathrm{m}^{-1}$ & 0.08 & [17] \\
\hline
\end{tabular}

a Payment for ecosystem services (Cultural Landscape Program in Brandenburg).

The total costs $\mathrm{TC}_{\mathrm{j}}$ for a management system consist of aggregated variable costs $\left(\mathrm{VC}_{\mathrm{ij}}\right)$ and corresponding fixed costs $\left(\mathrm{FC}_{\mathrm{j}}\right)$ (Equation (3)). In our analysis, $\mathrm{VC}_{\mathrm{ij}}$ for the products include repairs of machinery, the purchase of operating materials, seeds, fertilizers and pesticides, and costs for labor and energy, while $\mathrm{FC}_{\mathrm{j}}$ comprises insurance, rental, the depreciation of facilities and machinery, and interest (opportunity cost) [17,36]. The costs for each management system are grouped into blocks. For instance, in system 1, costs are divided into costs related to land use operations, costs due to fodder storage, costs from the milk-production process, and costs caused by the biogas plant. Management system 5 (barley) accordingly contains only the field operation cost.

$$
\mathrm{TC}_{\mathrm{j}}=\sum_{\mathrm{i}=1}^{\mathrm{n}} \mathrm{VC}_{\mathrm{ij}}+\mathrm{FC}_{\mathrm{j}}
$$

The results for cost, income and profit are presented per one hectare of fenland. This unit is chosen to allow subsequent calculations of greenhouse gas mitigation costs because greenhouse gas emissions from fenland use are commonly given in hectares [9,41].

The profitability of a fen management system is strongly affected by the producer price level. In the long run, total costs should be covered by income. Therefore, certain prices would be necessary to make the return to management of fen systems at least nonnegative. The break-even price indicates a price level where total costs are equal to income. It defines the profitability threshold. Beyond the break-even price, costs are not covered by income, which leads to an unprofitable management 
system [42]. We calculate a break-even price for each product of management systems while keeping the prices of other products constant, unless the respective price change is unable to equalize costs and income. In this case, it is labeled as "n/a" (not applicable).

Profitable management systems are defined as low profitable if the profit is between zero and $200 € \cdot$ ha $^{-1} \cdot$ year $^{-1}$ and highly profitable if profit exceeds $200 € \cdot$ ha $^{-1} \cdot$ year $^{-1}$. Management systems with profits below $0 € \cdot \mathrm{ha}^{-1} \cdot$ year $^{-1}$ are unprofitable.

Labor demand is calculated based on labor requirement per activity, mainly based on the KTBL database [41]. The data include working hours required per hectare for fieldwork, per cow, and per kWh electricity produced.

In the following subsections, we describe the assumptions and data that are used for the calculation of the economic figures, particularly for land use operations and biomass utilization.

\subsubsection{Economic Calculation Assumptions for Operations for Land Use}

Detailed working steps and the machinery used for the four land use systems with their 20 management systems are explained in Table 3.

Regarding mineral fertilization, the nutrient amount applied is the sum of the estimated nutrient export in marketed crops, milk, beef, and losses $\left(\mathrm{N}_{3} \mathrm{O}, \mathrm{N}_{2} \mathrm{O}\right.$ and $\left.\mathrm{NH}_{3}\right)$ [43,44]. As organic fertilizer, slurry from dairy cows and fattening bulls is returned to the cropland or intensive grassland where the forage plants are grown. In management systems producing biogas, digestate is applied to fields and accounts for the nutrient balance.

Reed canary grass (Phalaris arundinacea L.) can be cultivated on both extensive and intensive grassland for biogas production but without plowing and reseeding every year. An alternative way to use extensive permanent grassland is grazing for suckler cow husbandry. In this management system, half of the grassland is used for hay production for winter feeding, and the other half is used for grazing in summer. Another alternative use is short rotation coppice production with alder (Alnus glutinosa L.) as a suitable tree for wet conditions. We assume a longevity of 24 years for alder.

Reed cultivation is a peat-conserving practice on near-natural fens for which the groundwater level is close to the surface. No particular cultivation step is needed. The only requirement is that the reed be harvested on dry days after the vegetation period. Due to the high groundwater level, adapted machinery is necessary. In our investigation, we calculate the costs for a modified ski slope preparation caterpillar with a cutting device in front and a baling unit on top [15]. Near-natural fens are also considered natural reserves without any biomass use.

\subsubsection{Economic Calculation Assumptions for Biomass Utilization}

\section{Milk Production}

The dairy cows are kept in a stable. Their diet consists of maize silage, grass silage, and concentrate. We assume that all biomass, which is needed as feedstuff, is cultivated on fenland. Diets, the required land for growing forage plants, and cows fed per hectare are shown in Table 4.

The grass share in maize-dominated diets is assumed to be grown as field grass on fen cropland. Diets without maize silage contain field grass from intensive fen grassland [39]. Data on calculating the costs of dairy cow husbandry are given in Table 5.

\section{Beef Production}

In this study, beef is produced with fattening bulls or as a co-product in dairy and suckler cow husbandry. Fattening bulls are kept in a stable. The live weight at the time of slaughtering is $0.7 \mathrm{t}$. Their diet consists of grass or maize silage and concentrates (Table 4). For bull fattening, the costs include the purchase of bull calves, mineral feed expenditure, fees for animal health and consultation, and costs for mechanization, water and energy. Data on the calculation of the costs for bull fattening are given in Table 5. 
Table 3. Work flow, mechanization, and machinery costs of land use and management systems.

\begin{tabular}{|c|c|c|c|c|c|c|c|c|c|c|c|c|c|c|}
\hline \multirow[b]{2}{*}{ Crop } & \multirow{3}{*}{\multicolumn{2}{|c|}{$€ \cdot h a^{-1 *} \quad h \cdot h a^{-1}$}} & \multicolumn{4}{|c|}{ Cropland } & \multicolumn{2}{|c|}{ Intensive Grassland } & \multicolumn{4}{|c|}{ Extensive Grassland } & \multicolumn{2}{|c|}{ Near Natural Fen } \\
\hline & & & Maize & Barley & Potato & Grass & Grass & $\begin{array}{c}\text { Grass for } \\
\text { Combustion }\end{array}$ & $\begin{array}{l}\text { Grass for Sucker } \\
\text { Cow Husbandry }\end{array}$ & $\begin{array}{c}\text { Grass } \\
\text { Biogas }\end{array}$ & $\begin{array}{c}\text { Grass for } \\
\text { Combustion }\end{array}$ & $\begin{array}{l}\text { Short Rotation } \\
\text { Coppice }\end{array}$ & Reed & Unused \\
\hline & & & \multicolumn{12}{|c|}{ Number of cultivation steps per year } \\
\hline \multicolumn{15}{|l|}{ Tillage } \\
\hline Rotary cultivator (Ww $2.5 \mathrm{~m} ; \mathrm{Ep} 45 \mathrm{~kW}$ ) & 15.30 & 0.93 & - & - & - & - & - & - & - & - & - & 0.042 & - & - \\
\hline Ploughing (Ww 3.5 m; Ep $120 \mathrm{~kW}$ ) & 54.88 & 0.66 & - & - & - & 1 & - & - & - & - & - & - & - & - \\
\hline Mulching (Ww $2.5 \mathrm{~m} ; \mathrm{Ep} 45 \mathrm{~kW}$ ) & 32.18 & 1.22 & - & - & - & - & - & - & 1 & 1 & 1 & 0.083 & - & - \\
\hline Rolling (Ww 3 m; Ep 54 kW) & 15.30 & 0.68 & - & - & - & - & - & - & 1 & 1 & 1 & - & - & - \\
\hline Rolling (Ww 6 m; Ep 54 kW) & 9.94 & 0.34 & - & - & - & - & 1 & 1 & - & - & - & - & - & - \\
\hline 1. disc harrow ( $\mathrm{Ww} 6 \mathrm{~m} ; \mathrm{Ep} 120 \mathrm{~kW})$ & 17.82 & 0.22 & 1 & 1 & 1 & - & - & - & - & - & - & - & - & - \\
\hline 2. disc harrow ( $\left(W_{w} 6 \mathrm{~m} ; \mathrm{Ep} 120 \mathrm{~kW}\right)$ & 19.09 & 0.25 & 1 & 1 & 1 & - & - & - & - & - & - & - & - & - \\
\hline \multicolumn{15}{|l|}{ Fertilizer application } \\
\hline Pump (Ep $25 \mathrm{~kW}$ ) & 0.27 & & 1 & - & - & 1 & 1 & - & - & - & - & - & - & - \\
\hline Transport of digestate (Lc $\left.27 \mathrm{~m}^{3} ; \mathrm{Ep} 200 \mathrm{~kW}\right)$ & 2.00 & 0.20 & 1 & - & - & 3 & 3 & - & - & - & - & - & - & - \\
\hline Digestate application (Lc $20 \mathrm{~m}^{3}$; induction tool, Ww $24 \mathrm{~m}$; Ep1 $57 \mathrm{~kW}$ ) & 10.23 & 0.10 & 1 & - & - & 3 & 3 & - & - & - & - & - & - & - \\
\hline Mineral fertilizer transport (Lc trailer $8 \mathrm{t}$; Ep $54 \mathrm{~kW}$ ) & 4.30 & 0.30 & 1 & 3 & 1 & 1 & 1 & 1 & - & - & - & - & - & - \\
\hline Mineral fertilizer application (Lc $1.7 \mathrm{~m}^{3}$, Ww 24 m; Ep $83 \mathrm{~kW}$ ) & 6.49 & 0.08 & 1 & 3 & 1 & 1 & 1 & 1 & - & - & - & - & - & - \\
\hline \multicolumn{15}{|l|}{ Seeding/planting } \\
\hline Seeding Maize ( 8 lines, Ww $6 \mathrm{~m}$; Ep $54 \mathrm{~kW})$ & 45.28 & 0.35 & 1 & - & - & 1 & - & - & - & - & - & - & - & - \\
\hline Seeding barley $\left(\mathrm{WW}_{\mathrm{W}} 3 \mathrm{~m} ; \mathrm{Ep} 120 \mathrm{~kW}\right)$ & 58.12 & 0.85 & - & 1 & - & - & - & - & - & - & - & - & - & - \\
\hline Seeding potato (Ww 6 lines; $\mathrm{Ep} 120 \mathrm{~kW}$ ) & 62.38 & 0.60 & - & - & 1 & - & - & - & - & - & - & - & - & - \\
\hline Seeding grass ( $\mathrm{Ww} 3 \mathrm{~m}$; Ep $120 \mathrm{~kW})$ & 58.12 & 0.85 & - & - & - & - & 0.333 & 0.333 & - & 0.333 & - & - & - & - \\
\hline To hill up potato (Ww 6 lines; Ep $54 \mathrm{~kW}$ ) & 20.08 & 0.53 & - & - & 1 & - & - & - & - & - & - & - & - & - \\
\hline \multicolumn{15}{|l|}{ Pesticide application } \\
\hline Herbicide application (Ww 24 m, Lc 3000 L; Ep 54 kW) & 6.38 & 0.21 & 1 & 1 & 1 & - & - & - & - & - & 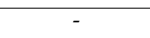 & - & - & - \\
\hline Fungicide/ insecticide application (Ww 24 m, Lc $3000 \mathrm{~L}$; Ep $54 \mathrm{~kW}$ ) & 6.38 & 0.21 & - & 2 & 5 & - & - & - & - & - & - & - & - & - \\
\hline \multicolumn{15}{|l|}{ Harvest } \\
\hline Mowing grass (Ww $3 \mathrm{~m}$; Ep $45 \mathrm{~kW}$ ) & 15.68 & 0.40 & - & - & - & 4 & 4 & 4 & & & & & & \\
\hline Mowing grass (Ww 2.4 m; Ep $45 \mathrm{~kW}$ ) & 12.17 & 0.48 & - & - & - & - & - & - & 0.5 & 1 & 1 & - & 1 & - \\
\hline Turning grass (Ww $10.75 \mathrm{~m}$; Ep $67 \mathrm{~kW}$ ) & 8.65 & 0.22 & - & - & - & 4 & 4 & 4 & - & - & 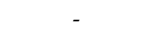 & - & - & - \\
\hline Turning grass (Ww $5.5 \mathrm{~m}$; Ep $45 \mathrm{~kW}$ ) & 8.02 & 0.29 & - & - & - & - & - & - & 0.5 & 1 & 1 & - & - & - \\
\hline Swathing hay (Ww $12.5 \mathrm{~m} ; \mathrm{Ep} 120 \mathrm{~kW}$ ) & 12.70 & 0.10 & - & - & - & 4 & 4 & 4 & - & - & - & - & - & - \\
\hline Swathing hay (Ww $4 \mathrm{~m} ; \mathrm{Ep} 45 \mathrm{~kW}$ ) & 9.64 & 0.32 & - & - & - & - & - & - & 0.5 & 1 & 1 & - & - & - \\
\hline Baling of hay (Lc round bales $1.2 \mathrm{~m} ; \mathrm{Ep} 54 \mathrm{~kW}$ ) & 19.46 & 0.33 & - & - & - & - & - & 4 & 0.5 & - & 1 & - & - & - \\
\hline Harvest by chipper for grass silage (Ep $275 \mathrm{~kW}$ ) & 33.21 & 0.20 & - & - & - & 4 & 4 & - & - & 1 & - & - & - & - \\
\hline Harvest by chipper for maize silage ( $W W$ & 115.98 & 0.33 & 1 & - & 1 & - & - & - & - & - & - & - & - & - \\
\hline Harvest by chipper for short rotation coppice (Ww 1 line, Ep $83 \mathrm{~kW}$ ) & 85.21 & 2.43 & - & - & - & - & - & - & - & - & - & 0.167 & - & - \\
\hline Transport of grass silage to silo (Lc 2 Trailer $8 \mathrm{t}$; Ep $67 \mathrm{~kW}$ ) & 10.56 & 0.40 & - & - & - & 1 & 1 & - & - & - & - & - & - & - \\
\hline Transport of grass silage to silo (Lc Trailer $8 \mathrm{t}$; Ep $54 \mathrm{~kW}$ ) & 29.71 & 2.29 & - & - & - & - & - & - & - & 1 & - & - & - & - \\
\hline Transport of maize silage to silo (Lc Trailer $40 \mathrm{~m}^{3} ; \mathrm{Ep} 120 \mathrm{~kW}$ ) & 78.31 & 1.94 & 1 & - & - & - & - & - & - & - & - & - & - & - \\
\hline Transport of barley to dealer (Lc Trailer $18 \mathrm{t}$; Ep $120 \mathrm{~kW}$ ) & 1.22 & 0.02 & - & - & 1 & - & - & - & - & - & - & - & - & - \\
\hline Transport of potato storage (Lc Trailer $8 \mathrm{t}$; Ep $67 \mathrm{~kW}$ ) & 24.07 & 0.63 & - & - & - & 1 & - & - & - & - & - & - & - & - \\
\hline Transport of hay (Lc Trailer $14 \mathrm{t}$; Front loader; Ep $67 \mathrm{~kW}$ ) & 9.40 & 0.40 & - & - & - & 1 & - & 1 & - & - & - & - & 1 & - \\
\hline Transport of hay (Lc 2 Trailer $8 \mathrm{t}$; Front loader; Ep $54 \mathrm{~kW}$ ) & 28.67 & 1.36 & - & - & - & - & - & - & - & - & 1 & - & - & - \\
\hline Transport of wood chips to storage (Lc Trailer $10 \mathrm{t} ; \mathrm{Ep} 67 \mathrm{~kW}$ ) & 33.96 & 2.42 & - & - & - & - & - & - & - & - & - & 0.167 & - & - \\
\hline Compaction in silo (Loader, Lc $13.5 \mathrm{t}$, Ep $105 \mathrm{~kW}$; front shovel $4 \mathrm{~m}^{3}$ ) & 18.39 & 0.97 & 1 & - & - & 1 & 1 & - & - & 1 & - & - & - & - \\
\hline Reed harvester caterpillar (Ww $3 \mathrm{~m}$ ) [45] & 408.76 & 2.00 & - & - & - & - & - & - & - & - & - & - & - & - \\
\hline Combine harvester (Lc 9500 L; Ep $225 \mathrm{~kW}$; Ww $7.5 \mathrm{~m}$ ) & 86.31 & 0.51 & - & 1 & - & - & - & - & - & - & - & - & - & - \\
\hline Leave chipping of potatoes (Ww 6 lines, Ep $54 \mathrm{~kW}$ ) & 22.42 & 0.53 & - & - & 1 & - & - & - & - & - & - & - & - & - \\
\hline Sorting of potato [39] & 416.00 & - & - & - & 1 & - & - & - & - & - & - & - & - & - \\
\hline
\end{tabular}

${ }^{*}$ Costs contain depreciation, repairs, operating material, diesel, interest, and others (costs per management step). Working width = Ww; Engine power = Ep; Load capacity = Lc. Source: Unless indicated otherwise, data is taken from [41]. 
Table 4. Assumed yield and feed ratio, and the required area.

\begin{tabular}{|c|c|c|c|c|c|c|c|c|c|c|c|c|c|}
\hline & \multirow[b]{2}{*}{ Yield/ha a } & \multicolumn{8}{|c|}{ Cropland } & \multicolumn{4}{|c|}{ Intensive Grassland } \\
\hline & & $\begin{array}{c}\text { Dairy Cow } \\
\text { (Maize) }\end{array}$ & Hectare/Cow & $\begin{array}{l}\text { Dairy Cow } \\
\text { (Grass) }\end{array}$ & Hectare/Cow & $\begin{array}{l}\text { Bull Fattening } \\
\text { (Maize) }\end{array}$ & Hectare/Bull & $\begin{array}{l}\text { Bull Fattening } \\
\text { (Grass) }\end{array}$ & Hectare/Bull & $\begin{array}{l}\text { Dairy Cow } \\
\text { (Grass) }\end{array}$ & Hectare/Cow & $\begin{array}{l}\text { Bull Fattening } \\
\text { (Grass) }\end{array}$ & Hectare/Bull \\
\hline & t DM ha ${ }^{-1}$ & $\%$ DM in Feed & ha. $\operatorname{cow}^{-1}$ & \% DM in Feed & ha. $\operatorname{cow}^{-1}$ & \% DM in Feed & ha.bull ${ }^{-1}$ & $\%$ DM in Feed & ha.bull ${ }^{-1}$ & $\%$ DM in Feed & ha. $\operatorname{cow}^{-1}$ & $\%$ DM in Feed & ha.bull ${ }^{-1}$ \\
\hline Barley & 5.16 & 4.9 & 0.0685 & 5.6 & 0.0735 & 5.0 & 0.03 & 5.35 & 0.03 & 5.62 & 0.0735 & 4.86 & 0.0286 \\
\hline Wheat & 5.418 & 12.2 & 0.1630 & 14.0 & 0.1749 & 12.4 & 0.07 & 13.37 & 0.08 & 14.04 & 0.1749 & 12.16 & 0.0682 \\
\hline Pea meal & 2.58 & 6.4 & 0.1815 & 7.4 & 0.1946 & 6.6 & 0.08 & 7.09 & 0.09 & 7.44 & 0.1946 & 6.44 & 0.0759 \\
\hline Rapeseed meal & 1.3932 & 0.1 & 0.0063 & 0.1 & 0.0068 & 0.1 & 0.00 & 0.13 & 0.00 & 0.14 & 0.0068 & 0.12 & 0.0027 \\
\hline Maize silage & 13 & 61.6 & 0.3439 & 0.0 & 0.0000 & 75.2 & 0.17 & 0.00 & 0.00 & 0.00 & 0.0000 & 0.00 & 0.0000 \\
\hline Grass silage & 10 & 14.1 & 0.1022 & 71.9 & 0.4855 & 0.0 & 0.00 & 73.26 & 0.23 & 71.92 & 0.6068 & 75.68 & 0.2874 \\
\hline ha cattle $e^{-1}$ & & & 0.8654 & & 0.9352 & & 0.35 & & 0.43 & & 1.06 & & 0.46 \\
\hline Cattle ha $^{-1}$ & & & 1.16 & & 1.07 & & 2.88 & & 2.33 & & 0.95 & & 2.16 \\
\hline
\end{tabular}

${ }^{a}$ Reference [17] 


\section{Calf Production}

Calves are the product of suckler and dairy cow husbandries. Suckler cows are kept outside on extensive grassland the entire year. Their live weight is estimated at $0.5 \mathrm{t}$. Calves are sold as fattening calves to fattening farms. Six calves are born during the 8-year lifetime of a suckler cow. Data on the calculation of the costs for suckler cow husbandry are given in Table 5.

Table 5. Data used for economic calculations of cattle husbandry.

\begin{tabular}{|c|c|c|c|}
\hline Parameter & Unit & Value & Reference \\
\hline \multicolumn{4}{|l|}{ Costs of dairy cow husbandry } \\
\hline Costs for stable (depreciation, interest, service) & $€ \cdot \operatorname{cow}^{-1}$ & 150.00 & [17] \\
\hline Interest (rate 6\%) & $€ \cdot \operatorname{cow}^{-1}$ & 60.00 & [17] \\
\hline Energy/water & $€ \cdot \operatorname{cow}^{-1}$ & 96.00 & [17] \\
\hline Animal health & $€ \cdot \operatorname{cow}^{-1}$ & 105.00 & [17] \\
\hline Insemination & $€ \cdot \operatorname{cow}^{-1}$ & 50.00 & [17] \\
\hline Purchase heifers & $€ \cdot \operatorname{cow}^{-1}$ & 1900.00 & [17] \\
\hline Mineral feed & $€ \cdot \operatorname{cow}^{-1}$ & 120.00 & [17] \\
\hline Labor demand & $h \cdot \operatorname{cow}^{-1}$ & 37.00 & [36] \\
\hline Other costs & $€ \cdot \operatorname{cow}^{-1}$ & 80.00 & [36] \\
\hline Producer price of milk & $€ \cdot \mathrm{kg}^{-1}$ & 0.28 & [46] \\
\hline \multicolumn{4}{|l|}{ Costs for beef production } \\
\hline Costs for stable (depreciation, interest, service) & $€ \cdot$ bull $^{-1}$ & 75.00 & [17] \\
\hline Interest (rate 6\%) & $€ \cdot$ bull $^{-1}$ & 50.00 & [17] \\
\hline Energy/water & $€ \cdot$ bull $^{-1}$ & 30.00 & [17] \\
\hline Animal health & $€ \cdot$ bull $^{-1}$ & 16.00 & [17] \\
\hline Purchase young bulls & $€ \cdot$ bull $^{-1}$ & 563.00 & [39] \\
\hline Mineral feed & $€ \cdot$ bull $^{-1}$ & 23.00 & [17] \\
\hline Labor demand & $\mathrm{h} \cdot \mathrm{bull}^{-1}$ & 4.50 & [41] \\
\hline Other costs & $€ \cdot$ bull $^{-1}$ & 15.00 & {$[17]$} \\
\hline Producer price of beef & $€ \cdot \mathrm{kg}^{-1}$ & 3.30 & [47] \\
\hline \multicolumn{4}{|l|}{ Costs of calf production } \\
\hline Costs of equipment (depreciation, interest, service) & $€ \cdot$ suckler $\cdot$ cow $^{-1}$ & 27.00 & [17] \\
\hline Interest (rate $6 \%$ ) & $€ \cdot$ suckler $\cdot$ cow $^{-1}$ & 20.00 & [17] \\
\hline Energy/water & $€ \cdot$ suckler $\cdot$ cow $^{-1}$ & 20.00 & [17] \\
\hline Animal health & $€ \cdot$ suckler $\cdot$ cow $^{-1}$ & 15.00 & [17] \\
\hline Insemination & $€ \cdot$ suckler $\cdot$ cow $^{-1}$ & 20.00 & [36] \\
\hline Mineral feed & $€ \cdot$ suckler $\cdot$ cow $^{-1}$ & 18.00 & [17] \\
\hline Labor demand & $\mathrm{h} \cdot$ suckler $\cdot \mathrm{cow}^{-1}$ & 8.00 & [36] \\
\hline Other costs & $€ \cdot$ suckler $\cdot$ cow $^{-1}$ & 40.00 & [17] \\
\hline Producer price of calves & $€ \cdot$ calf $^{-1}$ & 82.50 & [36] \\
\hline \multicolumn{4}{|l|}{ Costs of ensiling } \\
\hline Silage additives & $€ \cdot \mathrm{m}^{-3} \mathrm{FM}$ & 1.50 & [39] \\
\hline Silo foil & $€ \cdot \mathrm{m}^{-2}$ & 0.40 & [36] \\
\hline Depreciation & $€ \cdot \mathrm{m}^{-2}$ & 42.00 & [36] \\
\hline Service/repair silo & $€ \cdot \mathrm{m}^{-2}$ & 6.00 & [36] \\
\hline
\end{tabular}

Biogas Production

Maize silage, grass silage, and cattle slurry can be used as feedstock for biogas production. All the maize or grass silage obtained from the fenland in the respective management systems with sole biogas production is assumed to be used as part of a feedstock mix in a decentral biogas plant with an electric capacity of $500 \mathrm{~kW}$ and 8000 full-load hours per year. To calculate the revenues of energy generated based on one hectare, the specific biogas yield of considered feedstock per hectare is multiplied by an efficiency factor, the cost of biogas plant per $\mathrm{kWh}_{\mathrm{el}}$, and the electricity price. We assume that the electricity and heat generated in a combined heat and power unit are completely sold. The price 
for electricity was $0.1166 € \cdot \mathrm{kW} \cdot \mathrm{h}^{-1}$ in the second quarter of 2016 in Germany [48]. It is assumed that digestate is stored in leakage-free covered storage ready to apply on field. The feedstock of biogas plant is stored, with a $10 \%$ loss, in silos. The costs for silos, with a storage height of $3.5 \mathrm{~m}$, is $3.50 € \cdot \mathrm{ha}^{-1} \cdot$ year $^{-1} \cdot \mathrm{m}^{-3}$. Data on the calculation of the costs of biogas production are given in Table 6 .

Table 6. Data used for economic calculations of biogas production.

\begin{tabular}{|c|c|c|c|}
\hline Parameter & Unit & Value & Reference \\
\hline \multicolumn{4}{|l|}{ Characteristics of biogas plant } \\
\hline Process energy demand & percent of gross energy & 8 & [49] \\
\hline Methane yield of maize silage & $\mathrm{L} \cdot \mathrm{kg}^{-1} \mathrm{FM}$ & 101.15 & [50] \\
\hline Methane yield of grass silage from intensive grassland & $\mathrm{L} \cdot \mathrm{kg}^{-1} \mathrm{FM}$ & 115 & [51] \\
\hline Methane yield of grass silage from extensive grassland & $\mathrm{L} \cdot \mathrm{kg}^{-1} \mathrm{FM}$ & 84 & {$[51]$} \\
\hline Methane yield of cattle slurry & $\mathrm{L} \cdot \mathrm{kg}^{-1} \mathrm{FM}$ & 16.90 & {$[52]$} \\
\hline Biogas loss by leakage & $\%$ & 2 & [53] \\
\hline Electrical efficiency & $\%$ & 38.70 & {$[54]$} \\
\hline Thermal efficiency & $\%$ & 46.90 & [54] \\
\hline \multicolumn{4}{|l|}{ Costs of biogas plant } \\
\hline Depreciation (30 years) & $€ \cdot \mathrm{kWh}_{\mathrm{el}}{ }^{-1}$ & 0.0338 & {$[36]$} \\
\hline Interest (rate 6\%) & $€ \cdot \mathrm{kWh}_{\mathrm{el}}-1$ & 0.0082 & [36] \\
\hline Service/repair & $€ \cdot \mathrm{kWh}_{\mathrm{el}}^{-1}$ & 0.0197 & [36] \\
\hline Insurance & $€ \cdot \mathrm{kWh}_{\mathrm{el}}^{-1}$ & 0.0020 & [36] \\
\hline Laboratory analyses & $€ \cdot \mathrm{kWh}_{\mathrm{el}}^{-1}$ & 0.0004 & {$[36]$} \\
\hline Operating materials & $€ \cdot \mathrm{kWh}_{\mathrm{el}}^{-1}$ & 0.0130 & [36] \\
\hline Labor demand & $\mathrm{h} \cdot \mathrm{kWh}_{\mathrm{el}}{ }^{-1}$ & 0.0007 & {$[36]$} \\
\hline \multicolumn{4}{|l|}{ Revenues } \\
\hline Electricity (feed-in tariff) & $€ \cdot \mathrm{kWh}_{\mathrm{el}}{ }^{-1}$ & 0.1166 & [48] \\
\hline Heat (market price) & $€ \cdot \mathrm{kWh}_{\mathrm{th}}{ }^{-1}$ & 0.04 & [55] \\
\hline
\end{tabular}

FM: Fresh matter; $\mathrm{kWh}_{\mathrm{el}}$ : kilowatt hours of electricity; $\mathrm{kWh}_{\mathrm{th}}$ : kilowatt hours of heat.

\section{Combustion}

An alternative option for bioenergy production is the direct combustion of hay or reed after field drying $[14,15]$ for heat generation. The assumed capacity of the decentral combustion plant is $300 \mathrm{~kW}$ with 2500 full load hours per year. Dry feedstock such as hay is stored in a hall, and the investment costs are $40 € \cdot \mathrm{m}^{-3}$ over a lifespan of 50 years [36]. Heat generated from combustion can be sold to neighbored buildings, stables, and greenhouses. Data on the calculation of the costs for combustion are given in Table 7.

Table 7. Data used for calculation of costs for biomass combustion.

\begin{tabular}{|c|c|c|c|c|c|}
\hline & Unit & Reed/Hay & References & Wood Chips & References \\
\hline \multicolumn{6}{|l|}{ Characteristics of combustion plant } \\
\hline Energy content hay & $\mathrm{kWh} \cdot \mathrm{t}^{-1} \mathrm{DM}$ & 4000 & [56] & - & - \\
\hline Energy content reed & $\mathrm{kWh} \cdot \mathrm{t}^{-1} \mathrm{DM}$ & 3800 & [56] & - & - \\
\hline Energy content wood chips & $\mathrm{kWh} \cdot \mathrm{t}^{-1} \mathrm{DM}$ & - & - & 3800 & [55] \\
\hline Thermal efficiency & $\%$ & 70 & {$[56,57]$} & 70 & {$[56,57]$} \\
\hline \multicolumn{6}{|l|}{ Costs of biomass combustion } \\
\hline Investment costs & $€ \cdot \mathrm{kWh}_{\mathrm{th}}{ }^{-1}$ & 0.02 & [58] & 0.01 & [58] \\
\hline Operating life & years & 7 & [58] & 15.00 & [58] \\
\hline Rate of interest & $\%$ & 8 & [59] & 8 & [59] \\
\hline Service & $\%$ of investment cost & 2 & [59] & 2 & [59] \\
\hline Insurance & $\%$ of investment cost & 1 & [59] & 1 & [59] \\
\hline Feeding & $€ \cdot \mathrm{ha}^{-1}$ & 11.90 & [36] & 16.20 & [36] \\
\hline Administration & $\%$ of investment cost & 0.75 & [59] & 0.75 & [59] \\
\hline Other/insurance/administration & $€ \cdot \mathrm{kWh}_{\mathrm{th}}{ }^{-1}$ & 1.00 & [59] & 1.00 & [59] \\
\hline
\end{tabular}




\section{Results}

\subsection{Costs, Income, and Profits of Management Systems on Fenlands}

Most of the management systems achieved a positive return, if EU subsidies and payments for ecosystem services are included (Table 8 and Figure 1). The range of economic returns was between $-371 € \cdot \mathrm{ha}^{-1}$.year $^{-1}$ to $1622 € \cdot \mathrm{ha}^{-1}$.year ${ }^{-1}$ with subsidies and payments for ecosystem services. Without subsidies and environmental payments, the profits in all management systems decreased considerably, and the economic returns ranged from $-636 € \cdot$ ha $^{-1} \cdot$ year $^{-1}$ to $1363 € \cdot$ ha $^{-1} \cdot$ year $^{-1}$.

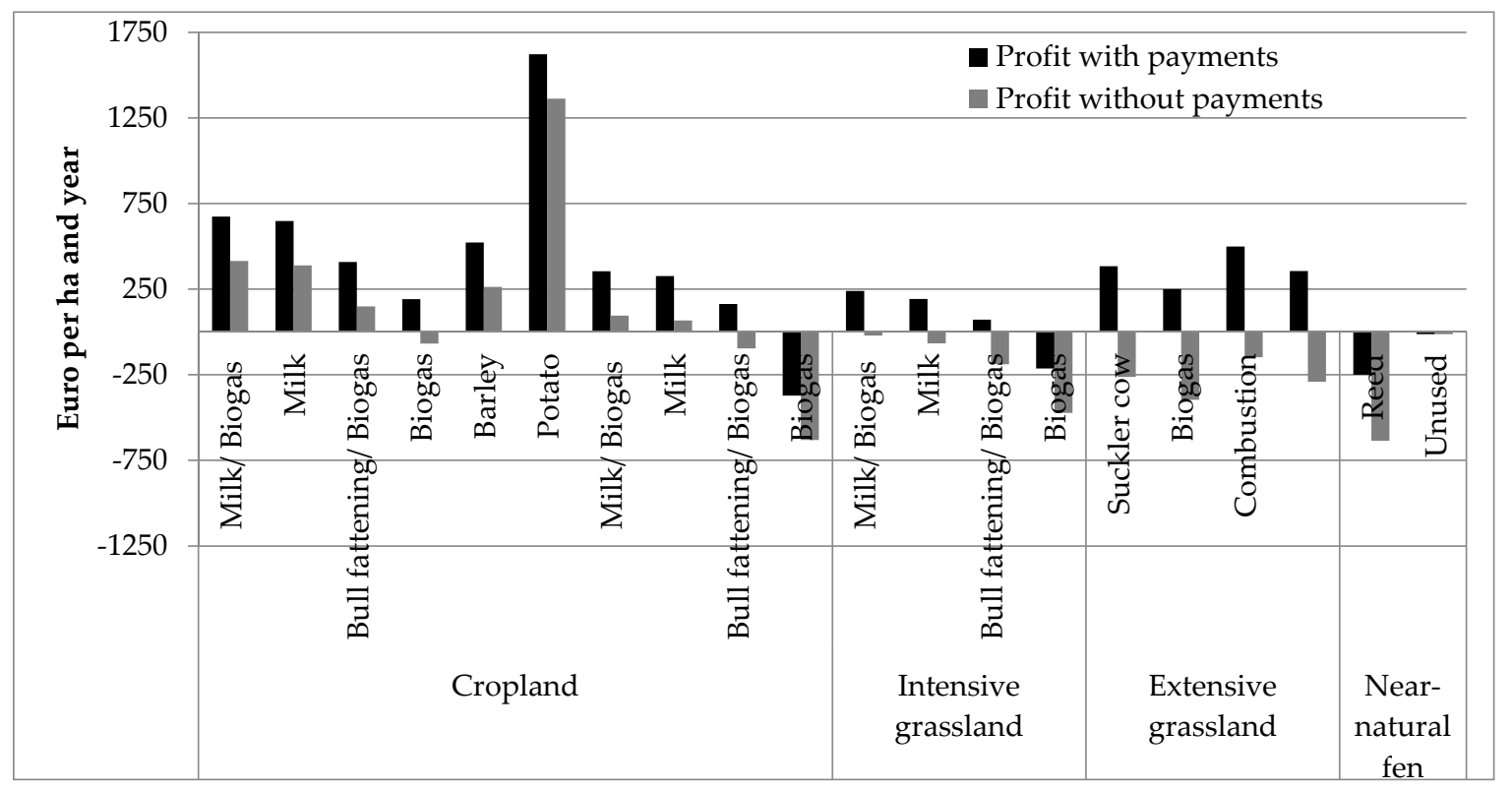

Figure 1. Fen management system profitability (Euro per hectare).

Although potato cultivation had the highest costs for biomass production, it resulted in the highest profit due to high yields and high product prices.

Barley as a cash crop is cultivated on fenland with sufficient water supply. There is no difference in cultivation compared to mineral soils. The average barley yield of $6 \mathrm{t} \cdot \mathrm{ha}^{-1}$.year ${ }^{-1}$ led to a profit of $263 € \cdot$ ha $^{-1} \cdot$ year $^{-1}$ without subsidies and $522 € \cdot$ ha $^{-1} \cdot$ year $^{-1}$ with subsidies.

Milk production based on maize silage was profitable due to the high yield and energy content of maize. The break-even price with subsidies was $0.2177 € \cdot \mathrm{kg}^{-1}$ for milk. Grass silage-based milk production was not profitable without subsidies. The break-even milk price with subsidies was $0.2545 € \cdot \mathrm{kg}^{-1}$ milk for dairy cows fed with grass silage from intensive grassland and $0.2418 € \cdot \mathrm{kg}^{-1}$ milk with field grass silage. 
Table 8. Cost, income, profit, and break even prices for fen management systems.

\begin{tabular}{|c|c|c|c|c|c|c|c|c|c|c|c|}
\hline \multirow{2}{*}{\multicolumn{2}{|c|}{\begin{tabular}{|l|} 
Land Use \\
Products
\end{tabular}}} & \multicolumn{10}{|c|}{ Cropland } \\
\hline & & Milk/Biog. & Milk & Bull Fat./Biogas & Biogas & Barley & Potato & Milk/Biog. & Milk & Bull Fat./Biogas & Biogas \\
\hline \multicolumn{2}{|l|}{ Main Crop } & Maize & Maize & Maize & Maize & Barley & Potato & Field Grass & Field Grass & Field Grass & Field Grass \\
\hline Cows fed per ha & cow'ha ${ }^{-1}$ & 1.16 & 1.16 & 2.88 & - & - & - & 1.07 & 1.07 & 2.33 & - \\
\hline \multicolumn{12}{|l|}{ Costs } \\
\hline Field & $€ \cdot h^{-1}$ & 821 & 820 & 680 & 821 & 688 & 2516 & 838 & 838 & 842 & 875 \\
\hline Storage/silo & $€ \cdot \mathrm{ha}^{-1}$ & 105 & 105 & 149 & 73 & - & - & 86 & 86 & 89 & 150 \\
\hline Milk production & $€ \cdot \mathrm{ha}^{-1}$ & 2137 & 2137 & - & - & - & - & 1944 & 1901 & - & - \\
\hline Beef production & $€ \cdot \mathrm{ha}^{-1}$ & - & - & 2869 & - & - & - & - & - & 2322 & - \\
\hline Biogas plant & $€ \cdot \mathrm{ha}^{-1}$ & 99 & - & 247 & 1057 & - & - & 92 & - & 200 & 498 \\
\hline Incineration plant & $€ \cdot \mathrm{ha}^{-1}$ & - & - & - & - & - & - & - & - & - & - \\
\hline \multicolumn{12}{|l|}{ Income } \\
\hline Beef & $€ \cdot \mathrm{ha}^{-1}$ & 454 & 454 & 3658 & - & - & - & 420 & 420 & 2960 & - \\
\hline Milk & $€ \cdot \mathrm{ha}^{-1}$ & 2912 & 2912 & - & - & - & - & 2395 & 2395 & - & - \\
\hline Calves sale & $€ \cdot \mathrm{ha}^{-1}$ & 84 & 84 & - & - & - & - & 78 & 78 & - & - \\
\hline Electricity & $€ \cdot \mathrm{ha}^{-1}$ & 133 & - & 332 & 1416 & - & - & 123 & - & 268 & 670 \\
\hline Heat & $€ \cdot \mathrm{ha}^{-1}$ & 42 & - & 105 & 470 & - & - & 39 & - & 85 & 222 \\
\hline Cash crops & $€ \cdot \mathrm{ha}^{-1}$ & - & - & - & - & 950 & 3879 & - & - & - & - \\
\hline EU-Subsidies & $€ \cdot h a^{-1}$ & 260 & 260 & 260 & 260 & 260 & 260 & 260 & 260 & 260 & 260 \\
\hline Environmental programs & $€ \cdot \mathrm{ha}^{-1}$ & - & - & - & - & - & - & - & - & - & - \\
\hline Income with payments & $€ \cdot \mathrm{ha}^{-1}$ & 3885 & 3710 & 4354 & 2245 & 1210 & 4139 & 3315 & 3153 & 3573 & 1151 \\
\hline Income without payments & $€ \cdot \mathrm{ha}^{-1}$ & 3625 & 3450 & 4095 & 1886 & 950 & 3879 & 3055 & 2893 & 3313 & 892 \\
\hline Total costs & $€ \cdot h a^{-1}$ & 3211 & 3062 & 3946 & 1953 & 688 & 2516 & 2960 & 2826 & 3453 & 1523 \\
\hline Variable costs & $€ \cdot \mathrm{ha}^{-1}$ & 1812 & 1774 & 2936 & 846 & 381 & 1567 & 1538 & 1503 & 2419 & 453 \\
\hline Profit with payments & & 674 & 648 & 409 & 218 & 522 & 1622 & 355 & 327 & 136 & -371 \\
\hline Profit without payments & $€ \cdot h a^{-1}$ & 414 & 388 & 149 & -42 & 263 & 1363 & 95 & 67 & -96 & -631 \\
\hline Break-even price with payments & & $\mathrm{n} / \mathrm{a}$ & - & $\mathrm{n} / \mathrm{a}$ & 0.1005 & - & - & $\mathrm{n} / \mathrm{a}$ & - & 0.0611 & 0.1813 \\
\hline Break-even price without payments & $€ \cdot \mathrm{kWh}_{\mathrm{el}}^{-1}$ & $\mathrm{n} / \mathrm{a}$ & - & 0.0642 & 0.1219 & - & - & 0.0264 & - & 0.1492 & 0.2265 \\
\hline Break-even price with payments & & 0.2152 & 0.2177 & - & - & - & - & 0.2385 & 0.2418 & - & - \\
\hline Break-even price without payments & $€ \cdot \mathrm{L}^{-1}$ milk & 0.2402 & 0.2427 & - & - & - & - & 0.2689 & 0.2721 & - & - \\
\hline Break-even price with payments & $f, c^{-1}$ bof & $\begin{array}{c}0.202 \\
-\end{array}$ & - & 2.9314 & - & - & - & - & - & 3.1178 & - \\
\hline Break-even price without payments & $€ \cdot \mathrm{kg}^{-1}$ beef & - & - & 3.1656 & - & - & - & - & - & 3.4072 & - \\
\hline Break-even price with payments & & - & - & - & - & 71.37 & 75.23 & - & - & - & - \\
\hline Break-even price without payments & $€ \cdot \mathrm{t}^{-1} \mathrm{FM}$ & - & - & - & - & 114.63 & 83.88 & - & - & - & - \\
\hline
\end{tabular}


Table 8. Cont.

\begin{tabular}{|c|c|c|c|c|c|c|c|c|c|c|c|}
\hline \multirow{2}{*}{\multicolumn{2}{|c|}{\begin{tabular}{|c|} 
Land Use \\
Products
\end{tabular}}} & \multicolumn{4}{|c|}{ Intensive Grassland } & \multicolumn{4}{|c|}{ Extensive Grassland } & \multicolumn{2}{|c|}{ Near-Natural Fen } \\
\hline & & \multirow{2}{*}{$\begin{array}{c}\text { Milk/ Biog. } \\
\text { Grass }\end{array}$} & \multirow{3}{*}{\begin{tabular}{|c|} 
Milk \\
Grass \\
0.95
\end{tabular}} & \multirow{3}{*}{$\begin{array}{c}\text { Bull Fat./ Biogas } \\
\text { Grass } \\
2.16\end{array}$} & \multirow{3}{*}{$\begin{array}{c}\text { Biogas } \\
\text { Grass } \\
-\end{array}$} & \multirow{2}{*}{$\begin{array}{l}\text { Suckle Cow } \\
\text { Grass Herbs } \\
\end{array}$} & \multirow{2}{*}{$\begin{array}{c}\text { Biogas } \\
\text { Grass }\end{array}$} & \multicolumn{2}{|c|}{ Combustion } & \multirow{2}{*}{$\begin{array}{l}\text { Reed } \\
\text { Reed } \\
\end{array}$} & \multirow{2}{*}{$\begin{array}{c}\text { Unused } \\
\text { Grass Herb }\end{array}$} \\
\hline & & & & & & & & Grass Herbs & Alder & & \\
\hline Cows fed per ha & cow $\cdot h^{-1}$ & 0.95 & & & & 0.6 & - & - & - & - & - \\
\hline \multicolumn{12}{|l|}{ Costs } \\
\hline Field & $€ \cdot \mathrm{ha}^{-1}$ & 849 & 849 & 859 & 665 & 173 & 403 & 225 & 331 & 581 & 13 \\
\hline Storage/silo & $€ \cdot \mathrm{ha}^{-1}$ & 95 & 95 & 103 & 121 & 48 & 88 & 114 & 15 & 245 & - \\
\hline Milk production & $€ \cdot \mathrm{ha}^{-1}$ & 1716 & 1683 & - & - & - & - & - & - & - & - \\
\hline Beef production & $€ \cdot \mathrm{ha}^{-1}$ & - & - & 2153 & - & 168 & - & - & - & - & - \\
\hline Biogas plant & $€ \cdot \mathrm{ha}^{-1}$ & 104 & - & 238 & 400 & - & 74 & - & - & - & - \\
\hline Incineration plant & $€ \cdot \mathrm{ha}^{-1}$ & - & - & - & - & - & - & 539 & 254 & 1306 & - \\
\hline \multicolumn{12}{|l|}{ Income } \\
\hline Beef & $€ \cdot \mathrm{ha}^{-1}$ & 372 & 372 & 2745 & - & 91 & - & - & - & - & - \\
\hline Milk & $€ \cdot \mathrm{ha}^{-1}$ & 2120 & 2120 & - & - & - & - & - & - & - & - \\
\hline Calves sale & $€ \cdot \mathrm{ha}^{-1}$ & 69 & 69 & - & - & 36 & - & - & - & - & - \\
\hline Electricity & $€ \cdot \mathrm{ha}^{-1}$ & 140 & - & 319 & 536 & - & 99 & - & - & - & - \\
\hline Heat & $€ \cdot \mathrm{ha}^{-1}$ & 44 & - & 101 & 178 & - & 33 & 730 & 309 & 1495 & - \\
\hline Cash crops & $€ \cdot \mathrm{ha}^{-1}$ & - & - & - & - & - & - & - & - & - & - \\
\hline EU-Subsidies & $€ \cdot \mathrm{ha}^{-1}$ & 260 & 260 & 260 & 260 & 260 & 260 & 260 & 260 & - & - \\
\hline Environmental programs & $€ \cdot \mathrm{ha}^{-1}$ & - & - & - & - & 387 & 387 & 387 & 387 & 387 & 0 \\
\hline Income with payments & $€ \cdot \mathrm{ha}^{-1}$ & 3004 & 2820 & 3425 & 973 & 774 & 815 & 1377 & 955 & 1882 & 0 \\
\hline Income without payments & $€ \cdot \mathrm{ha}^{-1}$ & 2745 & 2561 & 3165 & 713 & 127 & 168 & 730 & 309 & 1495 & 0 \\
\hline Total costs & $€ \cdot \mathrm{ha}^{-1}$ & 2765 & 2628 & 3353 & 1186 & 390 & 565 & 878 & 600 & 2132 & 13 \\
\hline Variable costs & $€ \cdot \mathrm{ha}^{-1}$ & 1403 & 1364 & 2277 & 302 & 227 & 218 & 270 & 343 & 450 & 0 \\
\hline Profit with payments & & 239 & 193 & 72 & -213 & 384 & 250 & 499 & 355 & -249 & -13 \\
\hline Profit without payments & $€ \cdot \mathrm{ha}^{-1}$ & -20 & -67 & -188 & -472 & -262 & -97 & -148 & -291 & -636 & -13 \\
\hline Break-even price with payments & & $\mathrm{n} / \mathrm{a}$ & - & 0.0904 & 0.1629 & - & $\mathrm{n} / \mathrm{a}$ & - & - & - & - \\
\hline Break-even price without payments & $€ \cdot k W h_{\mathrm{el}}$ & 0.1336 & - & 0.1854 & 0.2194 & - & 0.5852 & - & - & - & - \\
\hline Break-even price with payments & & 0.2484 & 0.2545 & - & - & - & - & - & - & - & - \\
\hline Break-even price without payments & $€ \cdot L^{-1}$ milk & 0.2827 & 0.2888 & - & - & - & - & - & - & - & - \\
\hline Break-even price with payments & & - & - & 3.2140 & - & $\mathrm{n} / \mathrm{a}$ & - & - & - & - & - \\
\hline Break-even price without payments & $€ \cdot \mathrm{kg}^{-1}$ beef & - & - & 3.5260 & - & 0.0128 & - & - & - & - & - \\
\hline Break-even price with payments & & - & - & - & - & - & - & - & - & - & - \\
\hline Break-even price without payments & $€ \cdot \mathrm{t}^{-1} \mathrm{FM}$ & - & - & - & - & - & - & - & - & - & - \\
\hline
\end{tabular}


Intensive bull fattening, based on maize silage from cropland, was profitable even without subsidies. Due to the high maize percentage in the diet, it was feasible to feed 2.88 bulls per ha. The annual profit of bull fattening was $409 € \cdot \mathrm{ha}^{-1} \cdot \mathrm{year}^{-1}$. The profit for bulls fed without maize silage was lower, with $163 € \cdot$ ha $^{-1}$.year ${ }^{-1}$ by field grass silage from cropland and $72 € \cdot$ ha $^{-1} \cdot$ year $^{-1}$ by grass silage from intensive grassland including the EU subsidies. Without them, bull fattening by grass silage from intensive grassland was not profitable, due to the lower grass yields. Grassland management led to higher production costs as a result of multiple harvests per year. Accordingly, less slurry for biogas production resulted in diminished revenue than maize silage-based bull fattening.

Suckler cow husbandry on extensive grassland was profitable only with the EU subsidies and payments for ecosystem services reaching a $384 € \cdot \mathrm{ha}^{-1} \cdot \mathrm{year}^{-1}$ net return. Due to the low market price for calves, the economic benefits were marginal.

Extensive hay production with a biomass yield of $5.8 \mathrm{t} \mathrm{DM} \mathrm{ha}^{-1} \cdot$ year $^{-1}$ led to an energy yield of $16,240 \mathrm{kWh}_{\text {th }} \cdot \mathrm{ha}^{-1} \cdot$ year $^{-1}$. This energy generation resulted in sales revenues of $730 € \cdot \mathrm{ha}^{-1} \cdot \mathrm{year}^{-1}$ and a profit of $499 € \cdot$ ha $^{-1} \cdot$ year $^{-1}$ with subsidies and environmental payments. The use of reed from near-natural fens was not profitable due to the current exclusion from the EU and environmental payments and because high costs for adapted machinery were double those on extensive grassland.

Short rotation coppice with alder was not economical without subsidies. Due to the high purchase costs of rooted alder plants, fixed costs were high $\left(257 € \cdot\right.$ ha $^{-1} \cdot$ year $\left.^{-1}\right)$. Because of low yield of $3.5 \mathrm{t} \mathrm{DM} \mathrm{ha}^{-1}$.year ${ }^{-1}$, a profitable cultivation for energetic use was possible only with subsidies and payments for ecosystem services.

The profitability of biogas production depends on production costs, biomass and methane yields and governmental payments within the individual management systems. For grass silage from cropland and intensive grassland, biomass and methane yields were too low to reach profitability. In contrast, biogas production from maize generated a profit of $192 € \cdot \mathrm{ha}^{-1} \cdot \mathrm{year}^{-1}$ with subsidies because of high energy yields per hectare. Producing biogas from grass silage from extensive grassland yielded a profit of $250 € \cdot \mathrm{ha}^{-1}$.year ${ }^{-1}$ due to payments for ecosystem services. The break-even price was $0.5852 € \cdot \mathrm{kWh}_{\mathrm{el}}{ }^{-1}$ without subsidies in this management system. The break-even price for electricity from grass silage from cropland was $0.1813 € \cdot \mathrm{kWh}_{\mathrm{el}}{ }^{-1}$ with subsidies, ceteris paribus. Energy based on grass from intensive grassland had a lower break-even price of $0.1629 € \cdot \mathrm{kWh}_{\mathrm{el}}{ }^{-1}$ with subsidies due to the lower yield level compared to grass yield on cropland. Cattle slurry as a byproduct of milk and beef production did not cause additional costs for feedstock supply except for pumping. At an electricity feed-in tariff of $0.1166 € \cdot \mathrm{kWh}_{\mathrm{el}}{ }^{-1}$, slurry use was profitable.

Near-natural fens provided no profits, leading to an annual loss of $13 € \cdot$ ha $^{-1} \cdot$ year $^{-1}$, due to the overhead costs.

\subsection{Labor Demand of Management Systems on Fens}

Labor demand ranged from zero $\mathrm{h} \cdot \mathrm{ha}^{-1} \cdot \mathrm{year}^{-1}$ for unused near-natural fens to $48.93 \mathrm{~h} \cdot \mathrm{ha}^{-1} \cdot \mathrm{year}^{-1}$ for combined milk and biogas production (Figure 2). For the same management systems in different land use systems, differences in labor demand were low. The management systems with combined milk and biogas production required the highest number of working hours per hectare and year. These systems included three major production steps: feedstuff production, animal keeping, and biogas production. Therefore, they required considerably more labor than solely crop production. Combined milk and biogas-production systems were followed by the bull fattening systems with integrated biogas production and the crop-based biogas-production systems.

Cash crops resulted in a high profit per working hour and hectare (Figure 3). Management systems in extensive grassland reached different profitable levels per working hour and hectare, if payments for ecosystem services are included. Among others, alder production for combustion yielded the second-highest profit per working hour and hectare after potato production, if payments are considered. All other management systems indicated low profitable to unprofitable levels per working hour. Profitability per working hour depended on labor demand per activity. Management systems with a high labor-demand intensity resulted in low profit per working hour. 

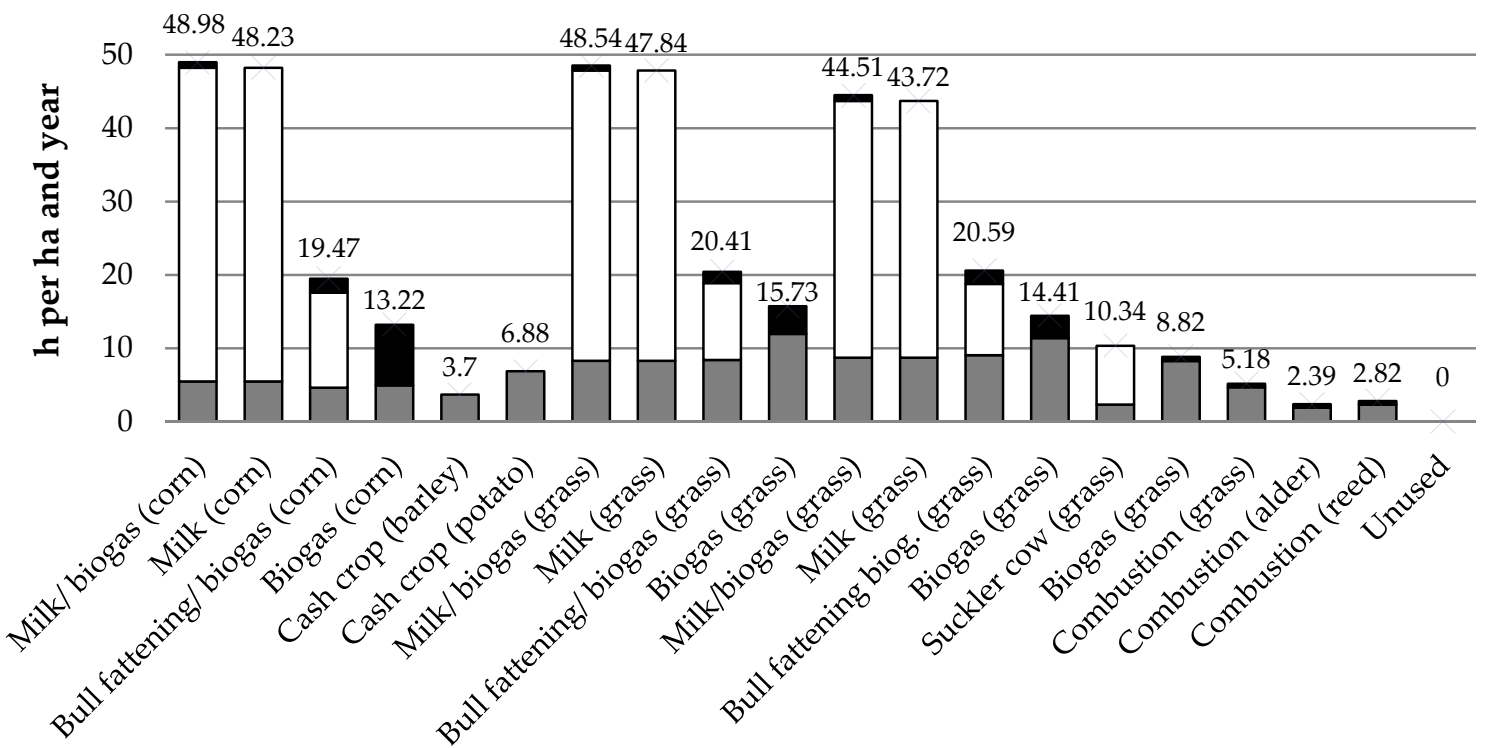

Labor demand on field $\quad \square$ Labor demand with animals $\quad$ Labor demand for energy

Figure 2. Labor demand of management systems on fenlands. n/a: Not applicable.

\section{Discussion}

To make agricultural production on fenland profitable, subsidies are necessary for most management systems. Payments for ecosystem services, i.e., the Cultural Landscape Program [38], and "Greening" [37] play a crucial role in the profitability of fenland use. Our study indicates that nearly all management systems on extensive grassland and near-natural fenlands are profitable with environmental payments in addition to the direct payments of the EU. Similar conclusions were drawn by Blokhina et al. [55]. GHG mitigation potentials of land use systems can be implemented in future studies for the assessment of effective policies including the allocation of the payments for ecosystem services.

The costs and yields of cash crops and maize silage on fenlands are comparable to those on mineral soils [17]. Our calculations for the costs of biomass supply from extensive grassland are in the range of Wichtmann and Haberl [15]. A higher groundwater level on extensive grassland allows one harvest per year, and additional payments for ecosystem services such as the Cultural Landscape Program increase farmers' profits considerably. Policy incentives are indispensable to promote peat-saving agricultural practices on fenlands because most of the management systems considered in this study led to low profitable or unprofitable outcomes from only market sales.

Potato production resulted in very high profitability with the assumed producer price of $142 € \cdot \mathrm{t}^{-1}$. The potato price is very volatile. It was $250 € \cdot t^{-1}$ in 2013 and dropped steeply to $80 € \cdot t^{-1}$ in 2014 [39]. If the price of 2014 is considered, this management system is unprofitable with or without subsidies. Additionally, potato cultivation requires special mechanization and know-how, and therefore, it is not widely spread.

The production costs of biomass on near-natural fen with an adapted caterpillar vehicle are $30 \%$ higher than our calculations, whereas our development costs for a modified caterpillar are $25 \%$ higher [18]. The exclusion of reed production from EU subsidies is another reason for the non-profitability of this management system. Reed receives payments only via the Cultural Landscape Program and is not considered among the EU funded crops [60]. If the EU subsidies were given, a profit level of $11 € \cdot \mathrm{ha}^{-1}$.year ${ }^{-1}$ could be reached for reed production. To maintain peat and to support employment in rural areas, it would be necessary to include reed in the EU-promoted crops. Thus, paludiculture could contribute to both the peat conservation and renewable energy targets of the EU [61]. 
Our calculations are based on a biogas plant with a capacity of $500 \mathrm{~kW}_{\mathrm{el}}$. According to the Renewable Energy Act (EEG) 2014 [48], the feed-in tariff for this capacity in Germany is currently approximately $0.1166 € \cdot \mathrm{kWh}_{\mathrm{el}}{ }^{-1}$, which makes biogas production unprofitable without subsidies and environmental payments. The positive return of biogas production from extensive grassland can be explained by payments for ecosystem services and by low input management, with one harvest per year and no fertilizer application. Blokhina et al. [55] assessed wetland use for biogas production in Germany in 2011 and identified biogas production as profitable under policy conditions at that time. Therefore, the profitability of biogas production strongly depends on the Renewable Energy Act. According to the revised act of 2014, feed-in tariffs will be determined by auction instead of being set by the government [48].

The milk price we consider $\left(0.28 € \cdot \mathrm{kg}^{-1}\right)$ is lower than the average price from FAOSTAT, i.e., $0.35 € \cdot \mathrm{kg}^{-1}$ (2010-2014) [62]. After the abolishment of the milk quota, farmers tended to invest in equipment and the expansion of livestock numbers [63]. The milk surplus led to a higher supply and accordingly a lower milk price. In the future, milk yield and price are expected to fluctuate $[64,65]$ because farmers are not limited to producing a fixed amount of milk. Our calculations indicate that milk production can be profitable on fenlands when subsidies are included.

Increased working hours per hectare may have a positive impact on employment in rural areas and thus contribute to the sustainability targets of the EU [66]. For instance, biomass supply for energy production can be a positive way to keep grassland in use and create new job opportunities [67]. Our results indicated a similar outcome for systems yielding multiple products. Nevertheless, the required working hours per hectare cannot be considered the only criterion for sustainable rural life. The profitability levels of management systems differ strongly. For instance, although biogas production by maize and grass silage requires more than double the number of working hours per hectare and year compared to barley and potato production, biogas production is not profitable, while barley and potato cultivation results in high profit levels per working hour and hectare (Figure 3). In addition to environmental motivations, social aspects can be considered to support biogas production, which may increase employment in rural areas.

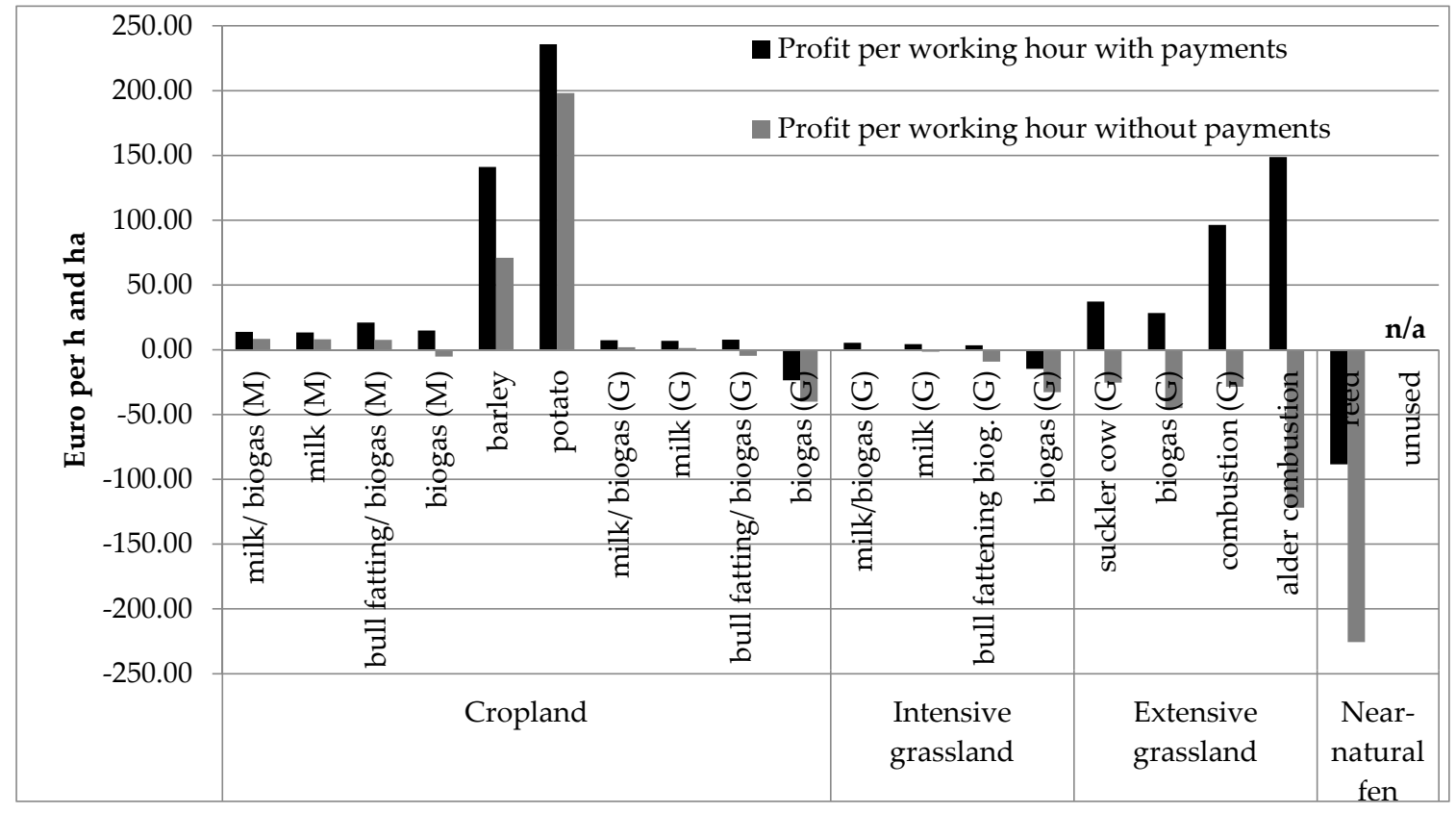

Figure 3. Utilization of labor in management systems on fenlands.

On natural fens, no subsidy is paid by the EU. To reward ecological benefits, such as the saving of rare adopted plant and animal species, and to avoid GHG emissions, $\mathrm{CO}_{2}$ certificates 
may be considered. This could be a onetime payment. In some federal states of Germany, individuals as well as companies can purchase carbon certificates to finance rewetting projects called "MoorFutures". Investors may offset emissions caused by their production by carbon certificate purchases. The ministries of the federal states are responsible for providing certificates [68].

Profits depend strongly on producer prices. Agricultural prices fluctuate during the course of the year and from year to year [69]. Considering these uncertainties, our study solely indicates profitability under the assumptions of the costs and prices taken here.

Previous studies have investigated single crops or single land use systems [14-17]. Our study provides a detailed overview of possible management systems on fenlands and a calculation of profitability.

Our calculations can be used as a basis for estimating greenhouse gas mitigation costs.

\section{Conclusions}

The profitability of fenland management systems in Brandenburg varies widely. Overall, the most profitable land use system on fenlands is cropland. Cash crops and milk production on cropland in particular are highly cost-effective options. If EU subsidies are considered, most management systems in intensive grassland are low profitable. With additional payments for ecosystem services, all management systems in extensive grassland are highly profitable. Near-natural fen use with or without payments is unprofitable. With the current electricity prices and feed-in tariffs, biogas production in all land use systems is identified as unprofitable to low profitable.

Subsidies and payments for ecosystem services are indispensable to promote peat-saving agricultural practices on fenlands. Extensive management systems and maintenance of near-natural fens may be considered a GHG-mitigation option on fenlands if economic losses due to higher groundwater levels are offset by incentives. In addition, the socio-economic dimension of change in management systems needs to be considered because management intensity level directly affects labor demand and accordingly employment in rural areas.

The results obtained in this study can be combined with GHG emissions to estimate GHG-mitigation costs. This could provide cost-efficient GHG-mitigation options on fenlands and identify options addressing the trade-off problem between economic benefits and environmental impacts.

Acknowledgments: The authors gratefully acknowledge the financial support by the Senate Competition Committee (SAW) within the Joint Initiative for Research and Innovation of the Leibniz Association (Grant Number: SAW-2013-ATB-4).

Author Contributions: Annette Prochnow and Marco Rebhann conceived and designed the study. Marco Rebhann compiled the data and performed the calculations. Yusuf Nadi Karatay and Günther Filler contributed to the data analysis and the selection of algorithms. Marco Rebhann, Yusuf Nadi Karatay and Annette Prochnow wrote the paper.

Conflicts of Interest: The authors declare no conflict of interest. The funding sponsors had no role in the design of the study; in the collection, analyses, or interpretation of data; in the writing of the manuscript, and in the decision to publish the results.

\section{References}

1. Josten, $\mathrm{H}$. The Global Peatland $\mathrm{CO}_{2}$ Picture-Peatland Status and Drainage Related Emissions in All Countries of the World; Wetlands International: Ede, The Netherlands, 2009.

2. Joosten, H.; Couwenberg, J. Peatlands and Carbon. In Assessment on Peatlands, Biodiversity and Climate Change-Main Report; Parish, F., Sirin, A., Charman, D., Joosten, H., Minayeva, T., Silvius, M., Stringer, L., Eds.; Global Environment Centre, Kuala Lumpur \& Wetlands International, Wageningen: Wageningen, The Netherlands, 2008; pp. 99-117.

3. Millennium Ecosystem Assessment. Ecosystems and Human Well-Being: Wetlands and Water Synthesis; World Resources Institute: Washington, DC, USA, 2005.

4. Wheeler, B.D.; Shaw, S. Classification of British Wetlands, 2nd ed.; 1.3 Some Other Wetland Terms; National Rivers Authority: Bristol, UK, 1995; pp. 7-10. 
5. Bedford, B.L.; Godwin, K.S. Fens of the United States: Distribution, characteristics, and scientific connection versus legal isolation. Wetlands 2003, 23, 608-629. [CrossRef]

6. Van den Pol-van Dasselaar, A.; van Beusichem, M.L.; Oenema, O. Methane emissions from wet grasslands on peat soil in a nature preserve. Biogeochemistry 1999, 44, 205-220. [CrossRef]

7. Leiber-Sauheitl, K.; Fuß, R.; Voigt, C.; Freibauer, A. High $\mathrm{CO}_{2}$ fluxes from grassland on histic Gleysol along soil carbon and drainage gradients. Biogeosciences 2014, 11, 749-761. [CrossRef]

8. Flessa, A.; Wild, U.; Kelmisch, M.; Pfadenhauer, J. Nitrouse oxid and methane fluxes from organic soils under agriculture. Eur. J. Soil Sci. 1998, 49, 327-335.

9. Blain, D.; Boer, R.; Eggleston, S.; Gonzalez, S.; Hiraishi, T.; Irving, W.; Krug, T.; Krusche, A.; Mpeta, E.J.; Penman, J.; et al. 2013 Introduction. In 2013 Supplement to the 2006 IPCC Guidelines for National Greenhouse Gas Inventories: Wetlands; Hiraishi, T., Krug, T., Tanabe, K., Srivastava, N., Jamsranjav, B., Fukuda, M., Troxler, T., Eds.; Intergovernmental Panel on Climate Change: Geneva, Switzerland, 2014.

10. Tubiello, F.; Biancalani, R.; Salvatore, M.; Rossi, S.; Conchedda, G. A worldwide assessment of greenhouse gas emissions from drained organic soils. Sustainability 2016, 8, 371. [CrossRef]

11. Renger, M.; Wessolek, G.; Schwärzel, K.; Sauerbrey, R.; Siewert, C. Aspects of peat conservation and water management. J. Plant Nutr. Soil Sci. 2002, 165, 487-493. [CrossRef]

12. Couwenberg, J. Emission Factors for Managed Peat Soils (Organic Soils, Histosols). An Analysis of IPCC Default Values; Wettlands International: Ede, The Netherlands, 2009.

13. Eickenscheidt, T.; Heinichen, J.; Drösler, M. The greenhouse gas balance of a drained fen peatland is mainly controlled by land-use rather than soil organic carbon content. Biogeosci. Discuss. 2015, 12, 5201-5258. [CrossRef]

14. Wichtmann, W.; Wichmann, S. Paludiculture-Site adapted management of re-wetted peatlands. TELMA 2011, 4, 215-234.

15. Wichtmann, W.; Haberl, A. 1 Möglichkeit der standortgerechten Niedermoorbewirtschaftung (Paludikultur). In Aktivierung der Klimaschutzfunktion von Niedermoorflächen in der Landeshauptstadt Potsdam-Handlungsleitfaden "Paludikultur"; Stadtverwaltung Potsdam-Koordinierungsstelle Klimaschutz: Potsdam, Germany, 2012; pp. 6-20. (In German)

16. Kowatsch, A.; Schäfer, A.; Wichtmann, W. Nutzungsmöglichkeiten auf Niedermoorstandorten-Umweltwirkungen, Klimarelevanz und Wirtschaftlichkeit Sowie Anwendbarkeit und Potenziale in Mecklenburg-Vorpommern; Ernst-Moritz-Arndt-Universität Greifswald: Greifswald, Germany, 2008. (In German)

17. Hanff, H.; Neubert, G.; Brudel, H. Datensammlung für die Betriebsplanung und die Betriebswirtschaftliche Bewertung Landwirtschaftlicher Produktionsverfahren im Land Brandenburg. Ackerbau/Grünlandwirtschaft/ Tierproduktion, 6; Ministerium für Infrastruktur und Landwirtschaft des Landes Brandenburg (MIL): Potsdam, Germany, 2010. (In German)

18. Cooper, M.; Lindegaard, K. Wetland Biomass to Bioenergy: Efficient Harvesting, Processing and Conversion of Wetland Biomass; Department of Energy \& Climate Change: Sheffield, UK, 2013.

19. Krimly, T.; Angenendt, E.; Bahrs, E.; Dabbert, S. Global warming potential and abatement costs of different peatland management options: A case study for the Pre-alpine Hill and Moorland in Germany. Agric. Syst. 2016, 145, 1-12. [CrossRef]

20. Röder, N.; Grützmacher, F. Emissionen aus landwirtschaftlich genutzten Mooren-Vermeidungskosten und Anpassungsbedarf. Natur und Landsch. 2012, 87, 56-61. (In German)

21. Deutscher Wetterdienst, Climate Data Center. Precipitation and Temperature data in Brandenburg (Average 1986-2015). Available online: http://www.dwd.de/DE/klimaumwelt/cdc/cdc_node.html (accessed on 14 July 2016).

22. Ministry of Rural Development, Environment and Agriculture of the Federal State of Brandenburg (2015) Peatland Map of Brandenburg. Available online: http://www.mlul.brandenburg.de/cms/detail.php/bb1.c. 331615.de (accessed on 14 July 2016).

23. Establishment and Management of Broadleaved Coppice. Available online: http://www.biomassenergycentre. org.uk/pls/portal/docs/page/bec_technical/best\%20practice/broadleavedcoppiceguiderevision $131007 \%$ 20gph.pdf (accessed on 31 July 2016).

24. Brix, H.; Sorrell, B.K.; Lorenzen, B. Are Phragmites-dominated wetlands a net source or net sink of greenhouse gases? Aquat. Bot. 2001, 69, 313-324. [CrossRef] 
25. Tanneberger, F.; Gatkowski, D.; Krogulec, J. 10.5 Poland-Paludiculture for biodiversity and peatland protection. In Paludiculture-Productive Use of Wet Peatlands Climate Protection-Biodiversity-Regional Economic Benefits; Wichtmann, W., Schröder, C., Joosten, H., Eds.; Schweizerbart Science Publishers: Stuttgart, Germany, 2016; pp. 207-211.

26. Allen, V.G.; Batello, C.; Berretta, E.J.; Hodgson, J.; Kothmann, M.; Li, X.; McIvor, J.; Milne, J.; Morris, C.; Peeters, A.; et al. An international terminology for grazing lands and grazing animals. Grass Forage Sci. 2011, 66, 2-28. [CrossRef]

27. Tölle, R.; Prochnow, A.; Kraschinski, S. Measuring techniques for the assessment of the trafficability of fen grasslands. Agrartech. Forsch. 2000, 55, 218-219.

28. Elsgaard, L.; Görresa, C.M.; Hoffmann, C.C.; Blicher-Mathiesen, G.; Schelde, K.; Petersen, S.O. Net ecosystem exchange of $\mathrm{CO}_{2}$ and carbon balance for eight temperate organic soils under agricultural management. Agric. Ecosyst. Environ. 2012, 162, 52-67. [CrossRef]

29. Schrier-Uijl, A.P.; Kroon, P.S.; Leffelaar, P.A.; van Huissteden, J.C.; Berendse, F.; Veenendaal, E.M. Methane emissions in two drained peat agro-ecosystems with high and low agricultural intensity. Plant Soil 2010, 329, 509-520. [CrossRef]

30. Veenendaal, E.M.; Kolle, O.; Leffelaar, P.A.; Schrier-Uijl, A.P.; van Huissteden, J.; van Walsem, J.; Möller, F.; Berendse, $\mathrm{F} . \mathrm{CO}_{2}$ exchange and Carbon balance in two grassland sites on eutrophic drained peat soils. Biogeosci. Discuss. 2007, 4, 1633-1671. [CrossRef]

31. Schrier-Uijl, A.P.; Kroon, P.S.; Hendriks, D.M.D.; Hensen, A.; van Huissteden, J.; Berendse, F.; Veenendaal, E.M. Agricultural peatlands: Towards a greenhouse gas sink-A synthesis of a Dutch landscape study. Biogeosciences 2014, 11, 4559-4576. [CrossRef]

32. Prochnow, A.; Kraschinski, S.; Tölle, R.; Hahn, J. Classes of load-input for agricultural machinery working on fen grasslands. Agrartech. Forsch. 1999, 5, 26-36. (In German)

33. Käding, H.; Kaiser, T.; Werner, A. Model for calculating grassland yields and forage quality in North-East Germany on the basis of site and management characteristics. Arch. Agron. Soil Sci. 2005, 51, 417-431. [CrossRef]

34. Statistical Office for Berlin-Brandenburg. 2013 Höhere Pachtpreise und Weniger Gepachtete Fläche in Brandenburg; Press Release No. 42; Amt für Statistik Berlin-Brandenburg: Potsdam, Germany, 2014. (In German)

35. Municipality Memorandum of Möllenhagen on Drainage Fees. Available online: http://www.amt-penzlinerland.de/media/custom/2225_152_1.PDF?1366622112 (accessed on 27 July 2016).

36. Kuratorium für Technik und Bauwesen in der Landwirtschaft e.V. Faustzahlen für die Landwirtschaft-14. Auflage; KTBL: Darmstadt, Germany, 2009. (In German)

37. The German Farmers' Association. Agricultural Subsidies-CAP Subsidy Estimator for Farmers until 2019-Direct Payments of Coming Years Calculated. Available online: http:/ /www.bauernverband.de/ praemienschaetzer (accessed on 26 July 2016).

38. State Office for Environment. Peat-Conservation Payments. AUKM Peat-Conservation Weir. Available online: http:/ /www.lfu.brandenburg.de/cms/detail.php/bb1.c.427130.de (accessed on 26 July 2016).

39. Hanff, H.; Lau, H. Datensammlung für die Betriebsplanung und die Betriebswirtschaftliche Bewertung Landwirtschaftlicher Produktionsverfahren im Land Brandenburg. Ackerbau/Grünlandwirtschaft/Tierproduktion, 7; Ministerium für Infrastruktur und Landwirtschaft des Landes Brandenburg (MIL): Potsdam, Germany, 2016. (In German)

40. Schlegel \& Co. Gartenprodukte GmbH (Basel, Switzerland). Personal communication, 2016.

41. Couwenberg, J.; Thiele, A.; Tanneberger, F.; Augustin, J.; Bärisch, S.; Dubovik, D.; Liashchynskaya, N.; Michaelis, D.; Minke, M.; di Skuratovich, A.; et al. Assessing greenhouse gas emissions from peatlands using vegetation as a proxy. Hydrobiologia 2011, 674, 67-89. [CrossRef]

42. Singh, S.P.; Deshpande, J.V. Break-even point. Econ. Polit. Wkly. 2016, 48, 123-128.

43. Hytönen, J. Effects of wood, peat and coal ash fertilization on Scots pine foliar nutrient concentrations and growth on afforested former agricultural peat soils. Silva Fenn. 2003, 37, 219-234. [CrossRef]

44. Svoboda, N.; Taube, R.; Wienforth, B.; Kluß, C.; Kage, H.; Herrmann, A. Nitrogen leaching losses after biogas residue application to maize. Soil Tillage Res. 2013, 130, 69-80. [CrossRef]

45. Timmermann, T. 3.2.1. Biomasse- und Standortkatalog (Standortpotenziale). In Bericht zum Forschungs-und Entwicklungsprojekt Energiebiomasse aus Niedermooren (ENIM); Wichmann, S., Wichtmann, W., Eds.; Universität Greifswald: Greifswald, Germany, 2009; pp. 37-48. (In German) 
46. Historical EU Price Serie of COW's RAW MILK in EURO/100 kg. Regulation (EC) No 479/2010 Article 2. Raw Milk Price in Germany: Average Price of June 2015-May 2016. Available online: http:/ / www.ec.europa. $\mathrm{eu} /$ agriculture/market-observatory/milk/pdf/eu-historical-price-series_en.xls (accessed on 27 July 2016).

47. FAOSTAT Online Database. Producer Price of Beef in Germany. Average Price of 2009-2013. Available online: http:/ / www.faostat3.fao.org/download/P/PP/E (accessed on 27 July 2016).

48. Deutscher Bundestag. Gesetz für den Ausbau erneuerbarer Energien (Erneuerbare-Energien-Gesetz-EEG 2014) EEG; Paragraph $\S 44$ Biomass; Federal Ministry of Justice and Consumer Protection: Berlin, Germany. (In German)

49. Naegele, H.J.; Lemmer, A.; Oechsner, H.; Jungbluth, T. Electric energy consumption of the full scale research biogas plant "Unterer Lindenhof": Results of long-term and full detail measurements. Energies 2012, 5, 5198-5214. [CrossRef]

50. Amon, T.; Amon, B.; Kryvoruchko, V.; Zollitsch, W.; Mayer, K.; Gruber, L. Biogas production from maize and dairy cattle manure-Influence of biomass composition on the methane yield. Agric. Ecosyst. Environ. 2007, 118, 173-182. [CrossRef]

51. Meyer-Aurich, A.; Lochmann, Y.; Klauss, H.; Prochnow, A. Comparative advantage of maize- and grass-silage based feedstock for biogas production with respect to greenhouse gas mitigation. Sustainability 2016, 8, 1-14. [CrossRef]

52. Miranda, N.D.; Granell, R.; Tuomisto, H.L.; McCulloch, M.D. Meta-analysis of methane yields from anaerobic digestion of dairy cattle manure. Biomass Bioenergy 2016, 86, 65-75. [CrossRef]

53. Tufvesson, L.M.; Lantz, M.; Börjesson, P. Environmental performance of biogas produced from industrial residues including competition with animal feed-Life-cycle calculations according to different methodologies and standards. J. Clean. Prod. 2013, 53, 214-223. [CrossRef]

54. Budde, J.; Prochnow, A.; Plöchl, M.; Suárez Quiñones, T.; Heiermann, M. Energy balance, greenhouse gas emissions, and profitability of thermobarical pretreatment of cattle waste in anaerobic digestion. Waste Manag. 2016, 49, 390-410. [CrossRef] [PubMed]

55. Blokhina, Y.; Prochnow, A.; Plöchl, M.; Luckhaus, C.; Heiermann, M. Concepts and profitability of biogas production from landscape management grass. Bioresour. Technol. 2011, 102, 2086-2092. [CrossRef] [PubMed]

56. Hartmann, H. Produktion, Bereitstellung und Eigenschaften biogener Festbrennstoffe. In Leitfaden Bioenergie Planung, Betrieb und Wirtschaftlichkeit von Bioenergieanlagen; Eltrop, L., Raab, K., Hartmann, H., Schneider, S., Schrüder, G., Fischer, J., Jahraus, B., Heinrich, P., Eds.; Fachagentur Nachwachsende Rohstoffe e. V.: Gülzow, Germany, 2000; pp. 52-89. (In German)

57. Fritsche, U.; Rausch, L.; Simon, K.-H. Umweltwirkungsanalyse von Energiesystemen: Gesamt-Emissions-Modell Integrierter Systeme (GEMIS) Endbericht; Öko-Institut, Büro Darmstadt: Darmstadt, Germany, 1989; pp. 113-161. (In German)

58. Hinge, J. Heating and Cooling with Biomass_Change of the Heating System on a Danish Pig Farm; EUBIONET III: Jyväskylä, Finland, 2010.

59. Schaubach, K.; Zeymer, M. Basisinformationen für eine Nachhaltige Nutzung von Landwirtschaftlichen Reststoffen zur Bioenergiebereitstellung, 13; 7 Technisch-ökonomische Analyse der Gesamtkonzepte; Deutsches Biomasseforschungszentrum: Leipzig, Germany, 2012; pp. 100-128. (In German)

60. Federal Ministry of Food and Agriculture. Implementation of EU Agricultural Reforms in Germany. Available online: http://www.bmel.de/SharedDocs/Downloads/Broschueren/UmsetzungGAPinD.pdf; jsessionid=B32510459EAC3D29EA56680229242E35.2_cid367?_blob=publicationFile (accessed on 27 July 2016).

61. European Commission. Renewable Energy. Available online: https://www.ec.europa.eu/energy/en/ topics/renewable-energy (accessed on 20 July 2016).

62. FAOSTAT Online Database. Producer Price of Milk in Germany. Average Price of 2010-2014. Available online: http:/ / www.faostat3.fao.org/download/P/PP/E (accessed on 27 July 2016).

63. Réquillart, V.; Bouamra-Mechemache, Z.; Jongeneel, R.; Penel, C. Economic Analysis of the Effects of the Expiry of the EU Milk Quota System; Final Report; Institut d'economie Industrielle: Brussels, Belgium, 2008.

64. Jongeneel, R.; van Berkum, S. What Will Happen after the EU Milk Quota System Expires in 2015? An Assessment of the Dutch Dairy Sector; LEI Wageningen UR: Wageningen, The Netherlands, 2015.

65. Hansen, B.G. An analysis of past world market prices of feed and milk and predictions for the future. Agribusiness 2016. [CrossRef] 
66. The European Parliament and the Council of the European Union. Regulation (EU) No 1306/2013 of the European Parliament and of the Council of 17 December 2013 on the Financing, Management and Monitoring of the Common Agricultural Policy and Repealing Council Regulations (EEC) No 352/78, (EC) No 165/94, (EC) No 2799/98, (EC) No 814/2000, (EC) No 1290/2005 and (EC) No 485/2008. Off. J. Eur. Union 2013, 347, 549-607.

67. Prochnow, A.; Heiermann, M.; Plöchl, M.; Linke, B.; Idler, C.; Amon, T.; Hobbs, P.J. Bioenergy from permanent grassland-A review: 1. Biogas. Bioresour. Technol. 2009, 100, 4931-4944. [CrossRef] [PubMed]

68. Joosten, H.; Brust, K.; Couwenberg, J.; Gerner, A.; Holsten, B.; Permien, T.; Schäfer, A.; Tanneberger, F.; Trepel, M.; Wahren, A. MoorFutures ${ }^{\circledR}$ Integration of Additional Ecosystem Services (Including Biodiversity) into Carbon Credits—Standard, Methodology and Transferability to Other Regions; BfN-Skripten 40; Bundesamt für Naturschutz (BfN) Federal Agency for Nature Conservation: Bonn, Germany, 2015.

69. FAOSTAT Online Database. Producer Price Indices in the Selected Country (2004-2006=100) $2002-2012$. Available online: http://www.faostat3.fao.org/download/P/PP/E (accessed on 27 July 2016).

(C) 2016 by the authors; licensee MDPI, Basel, Switzerland. This article is an open access article distributed under the terms and conditions of the Creative Commons Attribution (CC-BY) license (http://creativecommons.org/licenses/by/4.0/). 